Article

\title{
Removal of Paracetamol from Aqueous Solutions by Photocatalytic Ozonation over $\mathrm{TiO}_{2}-\mathrm{Me}_{\mathbf{x}} \mathrm{O}_{\mathrm{y}}$ Thin Films
}

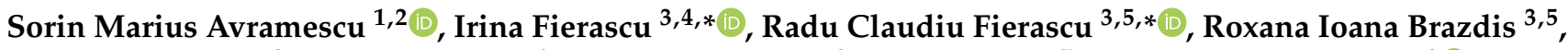 \\ Angel Vasile Nica ${ }^{2}$, Claudia Butean ${ }^{6}$, Elena Alina Olaru ${ }^{2}$, Sorin Ulinici ${ }^{7}$, Marian Nicolae Verziu ${ }^{8}(\mathbb{D}$ \\ and Anca Dumitru $9, *$ (D)
}

check for updates

Citation: Avramescu, S.M.; Fierascu, I.; Fierascu, R.C.; Brazdis, R.I.; Nica, A.V.; Butean, C.; Olaru, E.A.; Ulinici, S.; Verziu, M.N.; Dumitru, A. Removal of Paracetamol from Aqueous Solutions by Photocatalytic Ozonation over $\mathrm{TiO}_{2}-\mathrm{Me}_{\mathrm{x}} \mathrm{O}_{\mathrm{y}}$ Thin Films. Nanomaterials 2022, 12, 613. https://doi.org/10.3390/nano12040613

Academic Editor: Baizeng Fang

Received: 31 December 2021

Accepted: 6 February 2022

Published: 11 February 2022

Publisher's Note: MDPI stays neutral with regard to jurisdictional claims in published maps and institutional affiliations.

Copyright: (c) 2022 by the authors. Licensee MDPI, Basel, Switzerland. This article is an open access article distributed under the terms and conditions of the Creative Commons Attribution (CC BY) license (https:/ / creativecommons.org/licenses/by/ $4.0 /)$.
1 Department of Organic Chemistry, Biochemistry and Catalysis, Faculty of Chemistry, University of Bucharest, 050663 Bucharest, Romania; sorin.avramescu@g.unibuc.ro

2 PROTMED Research Centre, University of Bucharest, 050107 Bucharest, Romania; nica.angelvasile@yahoo.ro (A.V.N.); alina.olaru@g.unibuc.ro (E.A.O.)

3 Emerging Nanotechnologies Group, National Institute for Research \& Development in Chemistry and Petrochemistry-ICECHIM, 060021 Bucharest, Romania; roxana.brazdis@icechim.ro

4 Faculty of Horticulture, University of Agronomic Sciences and Veterinary Medicine of Bucharest, 011464 Bucharest, Romania

5 Department of Science and Engineering of Oxide Materials and Nanomaterials, Faculty of Chemical Engineering and Biotechnologies, University Politehnica of Bucharest, 011061 Bucharest, Romania

6 Department of Chemistry and Biology, North University Centre of Baia Mare, Technical University of Cluj-Napoca, 430122 Baia Mare, Romania; dee1168@yahoo.com

7 S.C. ICPE Bistrita S.A, 420035 Bistrita, Romania; sorin_ulinici@icpebn.ro

8 Department of Bioresources and Polymer Science, Advanced Polymer Materials Group, Faculty of Chemical Engineering and Biotechnologies, University Politehnica of Bucharest, 1-7 Gh Polizu Street, 011061 Bucharest, Romania; marian.verziu@upb.ro

9 Faculty of Physics, University of Bucharest, 077125 Magurele, Romania

* Correspondence: irina.fierascu@icechim.ro (I.F.); fierascu.radu@icechim.ro (R.C.F.); anka.dumitru@gmail.com (A.D.)

\begin{abstract}
Analgesics and nonsteroidal anti-inflammatory drugs (NSAIDs) such as paracetamol, diclofenac, and ibuprofen are frequently encountered in surface and ground water, thereby posing a significant risk to aquatic ecosystems. Our study reports the catalytic performances of nanosystems $\mathrm{TiO}_{2}-\mathrm{Me}_{\mathrm{x}} \mathrm{O}_{\mathrm{y}}(\mathrm{Me}=\mathrm{Ce}, \mathrm{Sn})$ prepared by the sol-gel method and deposited onto glass slides by a dip-coating approach in the removal of paracetamol from aqueous solutions by catalytic ozonation. The effect of catalyst type and operation parameters on oxidation efficiency was assessed. In addition to improving this process, the present work simplifies it by avoiding the difficult step of catalyst separation. It was found that the thin films were capable of removing all pollutants from target compounds to the oxidation products.
\end{abstract}

Keywords: catalytic ozonation; water treatment; paracetamol; photo-catalysis; thin films; titanium dioxide

\section{Introduction}

Water supplies are under a constant threat due to pollution resulting from numerous and complex anthropic activities. A special situation is represented by pharmaceuticals which escape traditional water treatment methods and reach the water bodies from multiple and almost uncontrollable sources [1-4]: effluents from pharmaceutical industries and hospitals, household disposal, the excretion of non-metabolized/metabolized drugs after human/animal consumption, aquaculture, sludge from water treatment facilities used as fertilizer and leaching drugs in ground water, etc. Moreover, along with parent compounds, the metabolites can also be harmful to aquatic ecosystems. The fraction of medicines that remain unchanged and leave patients' bodies ranges between 25\% and 75\% and, considering the large number of pharmaceuticals used worldwide, this results in a significant environmental burden which is growing due to an increase in world population 
in number and age. Thus, in 2020, 4.5 trillion doses of different drugs were used and 50\% of the world's population consume more than one dose [5] and, consequently, the concentration of pharmaceuticals in numerous natural water sources increase dramatically [6]. These compounds are encompassed (along with other largely used chemical compounds, such as hormones, plasticizers, wood treatment, pesticides, etc.) in the category of emerging pollutants (Eps) which are contaminants that are not currently regulated by environmental agencies. Another aspect of concern is that most of these compounds are also circumvented to the endocrine disruptor category that increases the danger for aquatic ecosystems.

Analgesics and nonsteroidal anti-inflammatory drugs (NSAIDs) like paracetamol, diclofenac, and ibuprofen are the most frequently encountered in surface and ground water, and therefore represent a significant risk for aquatic ecosystems [7,8]. Among them, paracetamol has an over-the-counter regime and is used intensively for pain relief and fever reduction. It is produced in staggering amounts, and the global acetaminophen market was valued at around US 850.5 million in 2020 and is expected to reach US 977.5 million in 2027, with a compound annual growth rate (CAGR) of around $2 \%$ [9]. In some countries, paracetamol consumption exceeds $20 \mathrm{~g}$ /person every year [10], thus it ends up in surface waters at concentrations of around $100 \mu \mathrm{g} / \mathrm{L}$ and surpasses tenfold the predicted noneffect concentration parameter (PNEC) which is $9.2 \mu \mathrm{g} / \mathrm{L}$. Hence, considering the huge environmental impact of this compound and its metabolites, it is important to reduce the spreading of this drug in different aquatic ecosystems. In fact, it is primarily a containment problem and, as to solve this issue, paracetamol leaking must be stopped, preferably at the source. In order to fulfill this difficult task, it is necessary to use a versatile and efficient water treatment method, with large applicability in terms of aqueous effluents flow rate, source type, and the removal of target pollutants at the level requested by environmental regulation (which are subject to change toward lower values in a rapid pace). Catalytic ozonation is a technique with a significant capacity to accomplish these requirements in every respect due to the capability to oxidize/mineralize almost every organic pollutant [11-21]. Moreover, this method is a prominent example of advanced oxidation processes-a well-known category of water treatment approaches centered on using $\mathrm{OH} \bullet$ radicals. This is the reason for a large number of studies regarding the development of catalytic systems capable of assisting the oxidative power of ozone mainly through the radical route. A large number of solids based on transitional metals in complex form or oxides, carbonaceous materials, etc., were studied for an evaluation of catalytic activity [22-30]. Additionally, catalyst precursors can be obtained from different industrial or agricultural wastes or pure metals salts. Despite that the catalytic ozonation process relies on a complex heterogeneous system (solid-gas-liquid), its performances are remarkable since most of these systems eliminate recalcitrant pollutants and set the quality parameters of treated water in the range established by environmental agencies. To be able to avoid the cumbersome separation step of the catalyst from treated water, a catalyst with a magnetic core was introduced [23,31-36]. Another interesting approach, that is unexploited in catalytic ozonation, although widely used in various other applications, is represented by thin films [37-44].

Well-known for its catalytic properties and chemical stability, $\mathrm{TiO}_{2}$ represents a very good candidate for the development of new nanosystems with an environmental application, however, its photocatalytic applications are limited, as a consequence of the large band gap $(\sim 3.2 \mathrm{eV})$ and fast recombination of the exciton of $\mathrm{TiO}_{2}$. This drawback can be overcome by the use of heterostructures of $\mathrm{TiO}_{2}$ and metal oxides with lower valence bands (i.e., $\mathrm{SnO}_{2}$ ), which hinders charge recombination, thus obtaining efficient photo-catalysis [45]. In an attempt to overcome another drawback in applying photo-catalysis to the treatment of polluted water (the recovery of the powder catalyst), $\mathrm{TiO}_{2}$-based thin films, immobilized on different supports (aerogels, polymers, glass, etc.) were successfully proposed in the literature $[46,47]$.

In this study, we report for the first time the removal of paracetamol from aqueous solutions using thin film catalysts based on $\mathrm{TiO}_{2}-\mathrm{Me}_{\mathrm{x}} \mathrm{O}_{\mathrm{y}}$ nanosystems deposited on glass plates 
and immersed into a semi-batch reactor. The influence of catalyst type and operational parameters in oxidation efficiency was assessed.

\section{Materials and Methods}

\subsection{Chemicals and Materials}

Commercially available reagents with a purity higher than $98 \%$ for solid compounds and an HPLC grade for solvents were purchased from Sigma-Aldrich (Baden-Württemberg, Germany): paracetamol, Triton X-100 (X100, polyethylene glycol tert-octyl phenyl ether), titanium tetraisopropoxide (TTIP), tin (IV) chloride pentahydrate, cerium (III) nitrate hexahydrate, acetic acid $(\mathrm{AcOH})$, ethanol $(\mathrm{EtOH})$, acetonitrile $(\mathrm{MeCN})$ and trifluoracetic acid (TFA). Borosilicate glass slides ( $25 \times 75 \mathrm{~mm}$ and a thickness of 1.0-1.2 mm) were obtained from Labbox (Barcelona, Spain). Airflow for ozone generation was provided by a laboratory compressor and distilled water with a resistivity of $18.2 \mathrm{M} \Omega . \mathrm{cm}$ was used in all experiments.

\subsection{Sol-Gel Synthesis}

In sol-gel synthesis usually, a pore directing agent is used and Triton X100 (a nonionic surfactant with long chain) was selected for this study. Triton X100 is an inexpensive and nontoxic amphiphilic molecule, with a significant capacity to accommodate inorganic structures in aqueous liquids. A solution of ethanol, Triton X100, and acetic acid were prepared and, in this mixture, TTIP was introduced under vigorous stirring. The molar ratio of these components (X100:EtOH:AcOH:TTIP = 1:70:5:1) was selected in order to achieve a higher specific surface based on optimization studies undertaken by Stathatos et al. [48]. Acetic acid and ethanol release water upon esterification and consequently, slow hydrolysis of TTIP take effect. Additionally, the acetic acid replaces, to some extent, the alkoxy groups in TTIP. Each mentioned metals salt was added to separate flasks containing the above-prepared solution in quantities, so Me is $5 \%$ of the TTIP content except for two metal modified thin films, where the percent of metal attain a cumulative $10 \%$.

\subsection{Preparation of Thin Films}

Glass slides were cleaned thoroughly in a succession of wash stages: detergent, water, acetone, and drying in $\mathrm{N}_{2}$ flow. Thin films were deposited on slides using the dip-coating method using a programmable system (80C-PTL-SC-6-LD, MTI, New York, NY, USA) following several steps: immersion and extraction of slides from solution at a rate of 10 $\mathrm{cm} / \mathrm{min}$ for three times with a 30 min pause between the dipping operation for drying at $60{ }^{\circ} \mathrm{C}$. Finally, each slide was calcined in a multistep programmable furnace (Nabertherm L5/11, Neuhausen, Germany) at a ramp rate of $5^{\circ} \mathrm{C} / \mathrm{min}$ to $550{ }^{\circ} \mathrm{C}$, maintained at $550{ }^{\circ} \mathrm{C}$ for $90 \mathrm{~min}$ and cooled down naturally. Prepared films on glass slides will be referred to as (Ti-Me) or (Ti-Me1-Me2) where Me = Ce, Sn.

\subsection{Thin Films Characterization}

The thin films' characterization was realized through several methods. The XRD patterns were recorded using Bruker D8 Discover equipment (Bruker AXS, Karlsruhe, Germany) $\left(\mathrm{Cu}_{\mathrm{k} \alpha 1}, \lambda=1.5406 \AA\right)$, between 15 and $70^{\circ}(2 \theta)$, in a grazing incidence configuration. The topography of the coated thin films was analyzed using an A.P.E Research SPM atomic force microscope (A.P.E. Research SRL, Trieste, Italy). DRIFT spectra of samples were collected in the region of $4000-500 \mathrm{~cm}^{-1}$ at a resolution of $2 \mathrm{~cm}^{-1}$ on a Varian 3100 Excalibur spectrometer (Walnut Creek, CA, USA) equipped with a Harrick Praying Mantis (Harrick Scientific Products, Inc., Pleasantville, NY, USA) diffuse reflectance accessory. UV-Vis absorption spectra of the films were carried out with a Helios alpha (Unicam, Cambridge, UK) spectrometer. The optical band gap [49-51] was evaluated by using the Tauc and Davis-Mott relation:

$$
\alpha h v=A\left(h v-E_{g}\right)^{n}
$$


where $\alpha$ is the absorption coefficient, $A$ is an energy-independent constant, $h v$ stands for photon energy, $E g$ is the optical energy band gap, and $n$ is considered to be the transition fingerprint. For $n=1 / 2,3 / 2,2$, and 3, it can be distinguish direct allowed, direct forbidden, indirect allowed, and indirect forbidden transitions, respectively. Tauc graphs were developed by plotting $\alpha h v^{\mathrm{n}}$ as a function of energy $(h v)$, and the point where the tangent of the reverse-extension curve intersects with the $x$-axis represents the band gap value of a semiconductor [49].

Raman spectra were carried out using a Renishaw in Via Confocal Raman (Renishaw, Wotton-under-Edge, Gloucestershire, UK) microscope system. The excitation laser wavelength was $473 \mathrm{~nm}$. The Raman spectra were acquired in the extended spectral region from 100 to $3200 \mathrm{~cm}^{-1}$, under ambient conditions.

\subsection{Photoreactor, Photocatalytic Activity, and Aqueous Effluents Analysis}

All experiments regarding oxidation of paracetamol were performed in a semi-batch jacketed cylindrical reactor with a capacity of $250 \mathrm{~mL}$ equipped with a Pen-Ray UV Light Source $254 \mathrm{~nm}$ (Cole-Parmer, Vernon Hills, IL, USA) protected by a quartz tube and placed centrally (Figure 1). Ozone was obtained from dried air using an ozone generator (COMAD-01, Anseros, Tübingen, Germany) and gas-phase ozone concentration was determined with an ozone analyzer (BMT 964, Stahnsdorf, Germany). The gas flow was supplied through a gas inlet into the reaction solution while simultaneously stirring at $1000 \mathrm{rpm}$, the temperature was kept at $20^{\circ} \mathrm{C}$ using a thermostat, and solution $\mathrm{pH}$ was measured (PHM 240, Radiometer S.A.S., Neuilly-Plaisance, France) by an electrode inserted directly into the solution and maintained at 7 by adding $\mathrm{HCl}$ or $\mathrm{NaOH}$ trough liquid inlets. Samples were withdrawn at certain time intervals (5 to $30 \mathrm{~min}$ ) to assure complete monitoring of the reaction course. The whole system was covered with aluminum foil as a deflector. Two or four glass slides with catalyst deposited on them were accommodated inside the reactor during the reaction. The reactor was filled with a $200 \mathrm{~mL}$ aqueous solution of paracetamol $(100 \mathrm{mg} / \mathrm{L})$. For repeated use, the catalytic slides were washed with distilled water and dried at $100{ }^{\circ} \mathrm{C}$ without any other treatment.

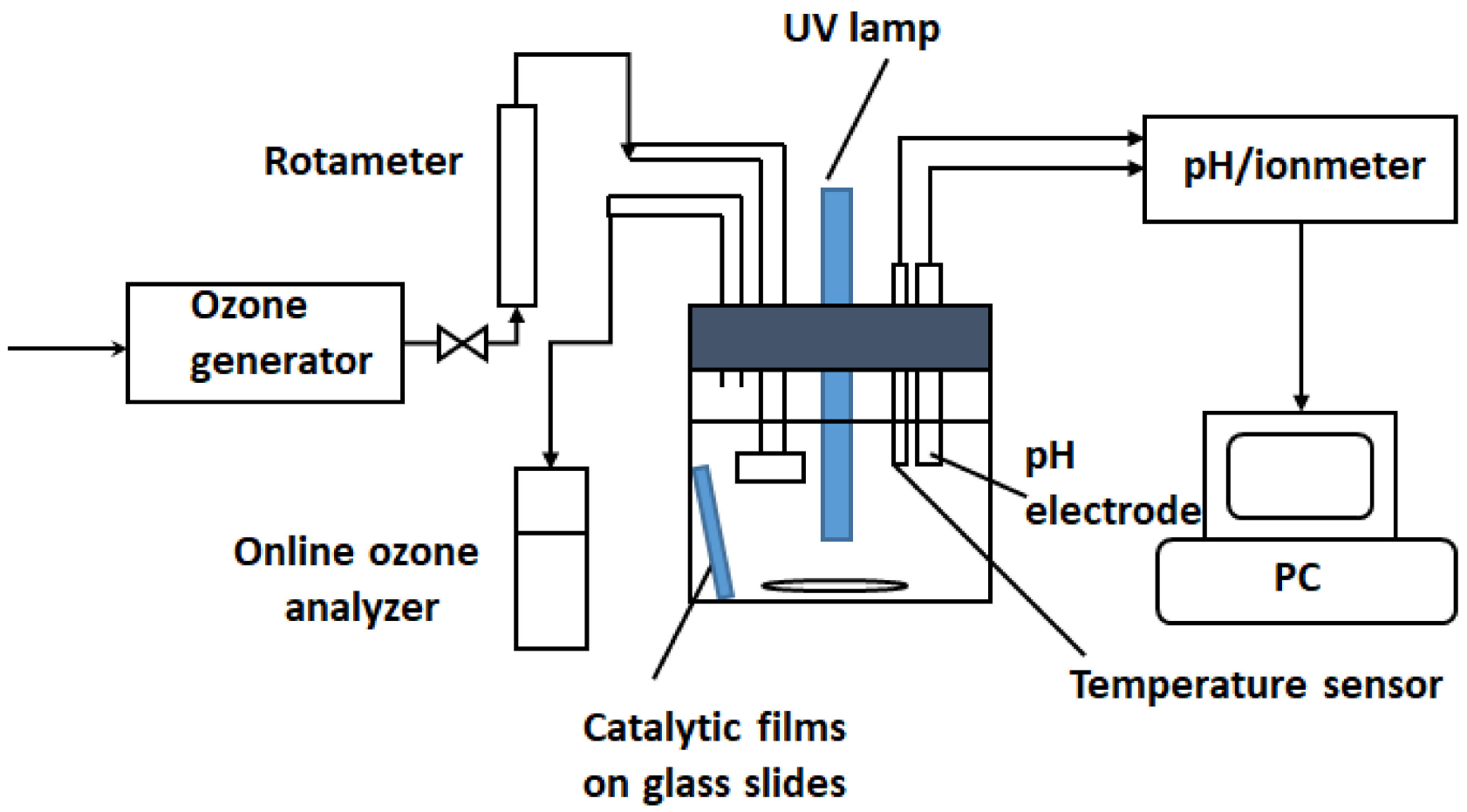

Figure 1. Experimental set-up for photocatalytic ozonation processes. 
Paracetamol concentration was determined by the HPLC method using an L-3000 system (Rigol Technologies Inc., Beijing, China) consisting of a quaternary pump, a diode-array detector, and a Kinetex C18 Evo $(150 \mathrm{~mm} \times 4.6 \mathrm{~mm}$ i.d.; $5 \mu \mathrm{m}$ particle size; Phenomenex, Torrance, CA, USA). Operating conditions were: isocratic elution of the mobile phase composed of eluent A (0.1\% TFA in acetonitrile); eluent B (0.1\% TFA in water) = 20:80, flow rate $1.0 \mathrm{~mL} / \mathrm{min}$, injection volume $10 \mu \mathrm{L}$, detection at $220 \mathrm{~nm}$ and $30{ }^{\circ} \mathrm{C}$. Ammonia and nitrate ions were determined using a Varian HPLC system ProStar (Varian Analytical Instruments, Palo Alto, CA, USA) equipped with a conductometric detector, a conductivity suppressor, and Dionex cation or anion columns (IONPAC AS 19-4 × $250 \mathrm{~mm}$ or IonPac CS19-4 × $250 \mathrm{~mm}$, Thermo Scientific, Waltham, MA. USA). Analysis was performed in isocratic mode with buffer carbonate/bicarbonate for nitrate and methanesulphonic acid for ammonia. Total organic carbon (TOC) measurements were achieved by the hightemperature oxidation method using a HiPerTOC (Thermo Electron, Waltham, MA, USA) analyzer. The absorbance of water samples at $254 \mathrm{~nm}$ (UV254) was measured using a Helios alpha (Unicam, Cambridge, UK) spectrometer.

\section{Results and Discussions}

\subsection{Thin Film Characterization}

The XRD patterns of the obtained materials are shown in Figure 2. The diffractograms of the as-prepared $\mathrm{TiO}_{2}$ film reveal a typical anatase structure (according to pdf file 00-0640863 from the International Centre of Diffraction Data 2019), with the most intense (101) peak at $2 \theta=25.08^{\circ}[52,53]$ and crystallite size of approximately $11.5 \mathrm{~nm}$, calculated using the Debye-Scherrer equation using the (101) peak. The diffractograms also presents other peaks, corresponding to the diffraction planes (004), (112), (200), (105), (211), and (204) at $2 \theta=37.7,38.6,48.1,53.9,55.1$, respectively, $62.7^{\circ}$. The XRD pattern for as-prepared (Ti-Ce) shows an additional peak compared with $\mathrm{TiO}_{2}$ films at around $30.3^{\circ}$, which is attributed to the $\mathrm{Ce}_{2} \mathrm{O}_{3}$ (101) plane according to pdf file 00-023-1048 from the International Centre of Diffraction Data 2019 [54]. According to literature data, the most probable explanation is related, on one hand, to a poor crystallization of the cerium oxide phase, which would not allow the indexation of other peaks, and on the other hand, to the low concentration of the phase, compared with the $\mathrm{TiO}_{2}$ support [55-57]. Other authors [57] identified the presence of both $\mathrm{CeO}_{2}$ and $\mathrm{Ce}_{2} \mathrm{O}_{3}$ phases in the XRD data; however, in our obtained diffractograms, no discernable peaks that can be attributed to a $\mathrm{CeO}_{2}$ phase could be identified. The crystallite size of the $\mathrm{TiO}_{2}$ phase was calculated to be approximately $12 \mathrm{~nm}$, while the crystallite size of the the $\mathrm{Ce}_{2} \mathrm{O}_{3}$ phase was approximately $19 \mathrm{~nm}$. The main conclusion is that $\mathrm{Ce}_{2} \mathrm{O}_{3}$ has little effect on the crystal structure of $\mathrm{TiO}_{2}$. The XRD pattern of (Ti-Sn) films shows that the diffraction peaks corresponding to the anatase phase are slightly wider, with a crystallite size of approximately $13 \mathrm{~nm}$. Additionally, the diffractogram reveals the presence of the specific amorphous phase peak, around $25^{\circ}(2 \theta)$. Moreover, an additional contribution in the diffraction pattern of (Ti-Sn) films which are attributed to the tetragonal $\mathrm{SnO}_{2}$ plane (110) can be observed at $2 \theta=26.6^{\circ}$, in concordance with pdf file data from the International Centre of Diffraction Data 2019 (00-005-0467), with a crystallite size corresponding to the $\mathrm{SnO}_{2}$ phase over $20 \mathrm{~nm}$. Several other minor peaks are present in the Ti-Sn diffractogram, which can be attributed to the presence of secondary phase, most probably $\mathrm{Sn}_{2} \mathrm{O}_{3}$ (ICDD PDF card no. 00-025-1259), as suggested by the presence of minor diffraction peaks at $2 \theta=27.4,31.4$, and $55.9^{\circ}$, corresponding to the diffraction planes (011), (021), respectively (141). The diffraction pattern of as-prepared Ti-Ce-Sn does not show any diffraction peaks except an overlap contribution of around $25^{\circ}(2 \theta)$, which indicates an amorphous nature of the thin film. Similar amorphous films were also reported by other authors, at a relatively $\mathrm{Ti} / \mathrm{Me}$ ratio [58]. 


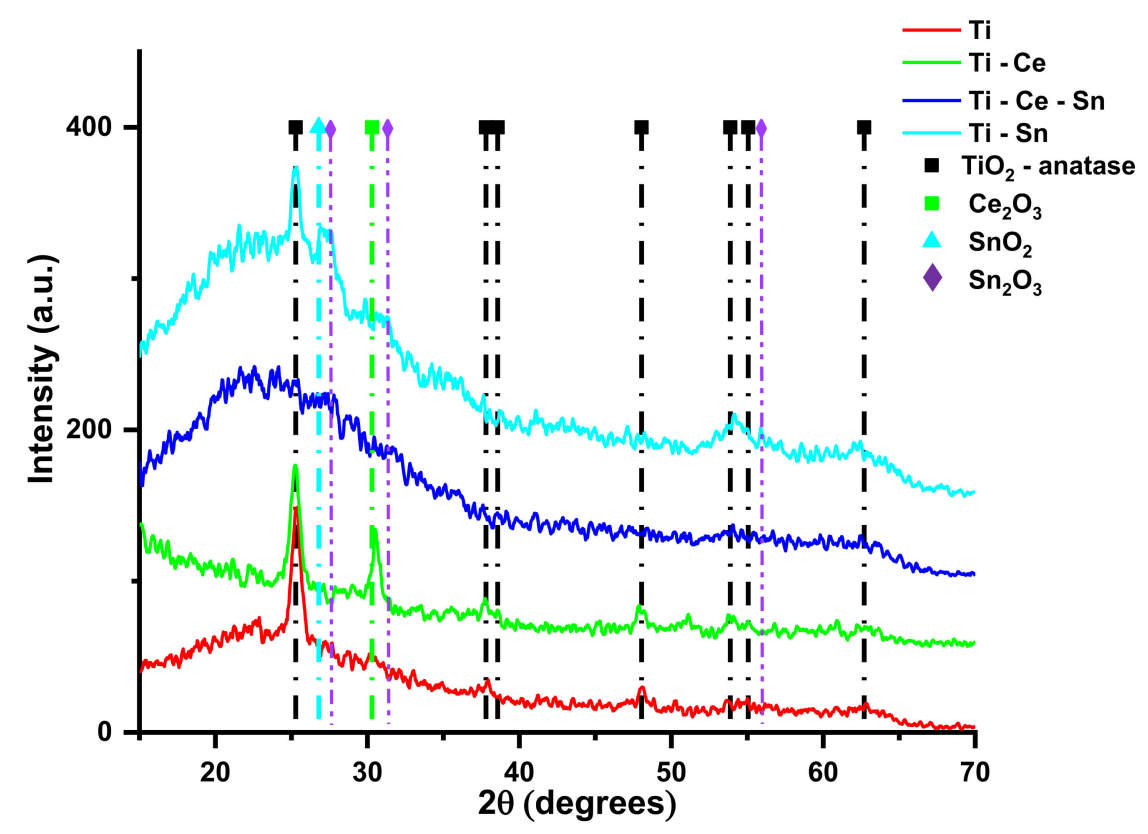

Figure 2. $\mathrm{XRD}$ patterns of $\mathrm{TiO}_{2}-\mathrm{Me}_{\mathrm{x}} \mathrm{O}_{\mathrm{y}}$ films.

For the prepared thin films, AFM images and surface data are presented in Figure 3 and Table 1 , showing that all modified $\mathrm{TiO}_{2}-\mathrm{Me}$ films were rougher than the simple $\mathrm{TiO}_{2}$ films. In terms of catalytic activity, increased surface irregularities are subject to providing more active sites therefore faster removal of pollutants.
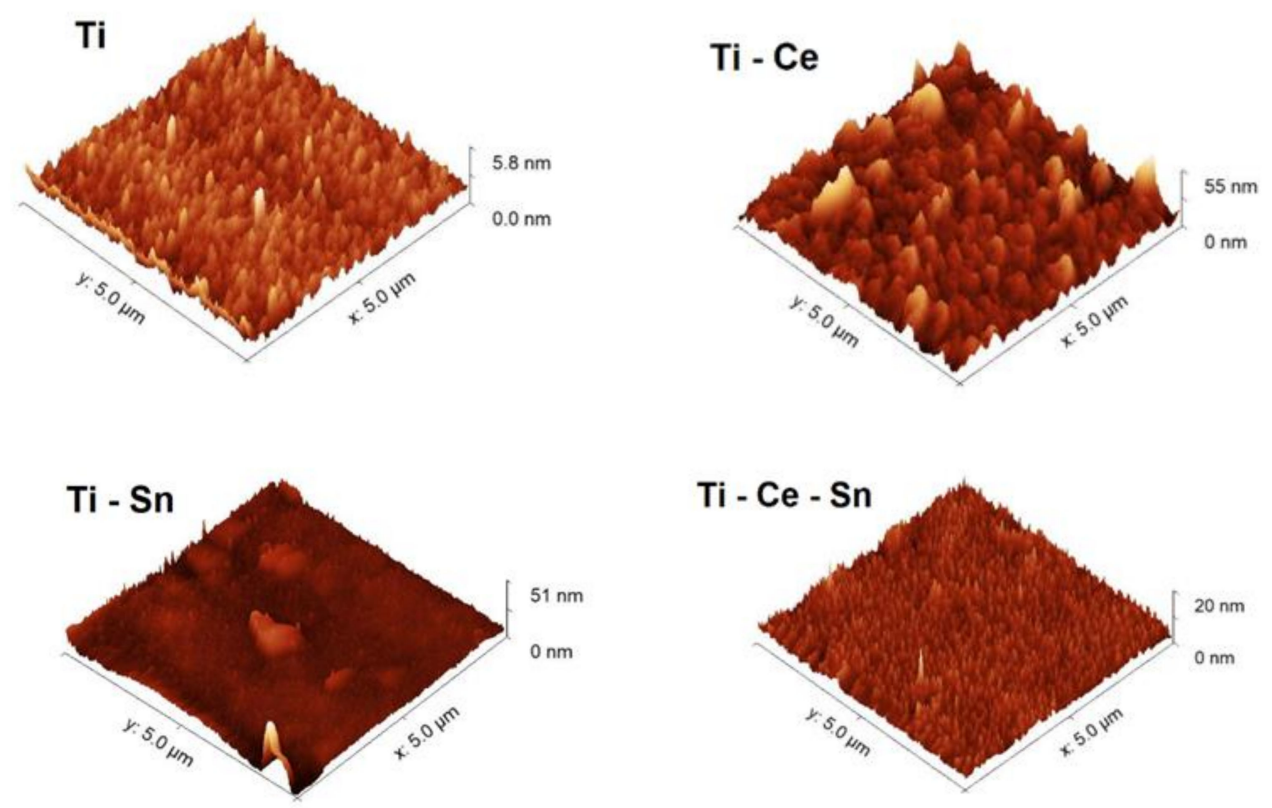

Figure 3. AFM images of $\mathrm{TiO}_{2}-\mathrm{Me}_{\mathrm{x}} \mathrm{O}_{\mathrm{y}}$ films.

Table 1. The roughness of the prepared films.

\begin{tabular}{cc}
\hline Sample & RMS Roughness $(\mathbf{n m})$ \\
\hline$(\mathrm{Ti})$ & 1.1 \\
$(\mathrm{Ti}-\mathrm{Ce})$ & 5.9 \\
$(\mathrm{Ti}-\mathrm{Sn})$ & 2.97 \\
$(\mathrm{Ti}-\mathrm{Ce}-\mathrm{Sn})$ & 2.1 \\
\hline
\end{tabular}


Raman spectroscopy is a widely used tool to detect chemical bonds as well as to identify the crystalline state of metal oxides. Raman spectra (Figure 4) for all prepared films were performed under ambient conditions. The band at $143 \mathrm{~cm}^{-1}$ assigned to $\mathrm{TiO}_{2}$ anatase structure [59] is well highlighted for all materials, except for the Ti-Ce-Sn sample, where the presence both of cerium and tin led to an increase of bands intensity at 244,455 , and $612 \mathrm{~cm}^{-1}$ which corresponds to the rutile phase [60]. Moreover, $\mathrm{SnO}_{2}$ promotes the crystallization of the $\mathrm{TiO}_{2}$ in the rutile phase [61,62], which justifies the presence of the bands' characteristics for rutile structure regarding the Ti-Sn films. On the other hand, in the presence of $\mathrm{Ce}$, the Raman bands are below $700 \mathrm{~cm}^{-1}$ and could be assigned to $\mathrm{TiO}_{2}$ as anatase [63].

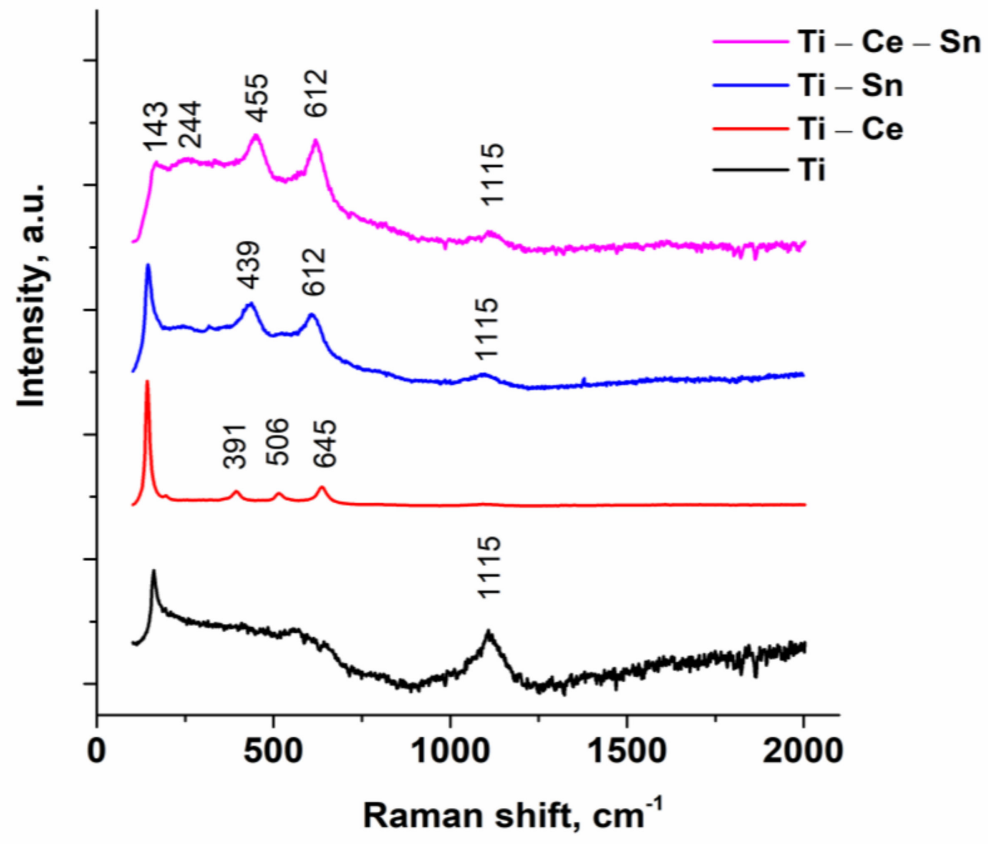

Figure 4. Raman spectra of prepared film.

Anatase presence is consistent with data obtained from XRD patterns. In the case of the (Ti-Ce) system, three bands at 391, 506 and $645 \mathrm{~cm}^{-1}$ confirm the formation of crystalline $\mathrm{CeO}_{2}[64,65]$. The spectra for (Ti-Sn) systems present bands at $442 \mathrm{~cm}^{-1}$ with a shift at $455 \mathrm{~cm}^{-1}$ for (Ti-Ce-Sn), a result of Eg vibration mode for the rutile phase of $\mathrm{SnO}_{2}$ and at $612 \mathrm{~cm}^{-1}$ for both systems attributed surface phonon modes of $\mathrm{SnO}_{2}$ [66]. For all spectra, the band at $1115 \mathrm{~cm}^{-1}$ corresponds to a glass substrate.

FTIR spectra (Figure S1, Supplementary Material) were collected for pristine films and those used in the oxidation reaction. Borosilicate glass slides present a characteristic band assigned to $\mathrm{Si}-\mathrm{O}$ bonds $\left(559,1287 \mathrm{~cm}^{-1}\right), \mathrm{Bi}-\mathrm{O}\left(826,2162 \mathrm{~cm}^{-1}\right), \mathrm{OH}$ groups $\left(3532 \mathrm{~cm}^{-1}\right)$, and the spectra for (Ti) and (Ti-Ce) films mimics glass spectra, probably due to higher transparency. In the case of (T-Sn) and (Ti-Ce-Sn) systems, FTIR spectra are significantly flattened as the thickness increases. FTIR spectra were also used as a tool for assessing the preservation of film integrity during the oxidation process and it can be observed that the thin films preserve their integrity.

The UV-VIS absorption spectra and Tauc plots of modified $\mathrm{TiO}_{2}$ thin films were presented in Figure 5 and the estimated band gaps $(E g)$ are presented in Table 2. Lower values of $\mathrm{E}_{\mathrm{g}}$ for $\mathrm{Ce}$ modified films can be attributed to partial substitution of Ti cations and/or $\mathrm{TiO}_{2}$ crystal size [67]. From the transmittance spectra, it can be observed that prepared films are highly transparent in the visible region with a red shift of (Ti-Ce), (TiCe-Sn) compared with (Ti) and (Ti-Sn) and this is an indication that these films have a narrow bandwidth [65]. Increased transmission is also linked with film crystallinity [68] and consequently, to photocatalytic activity. 


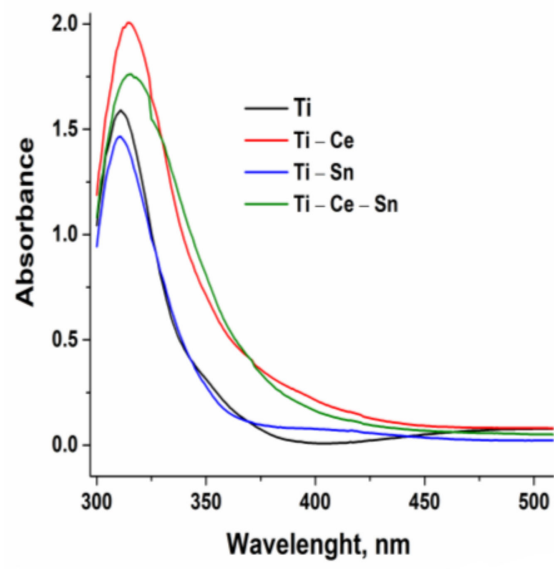

(a)

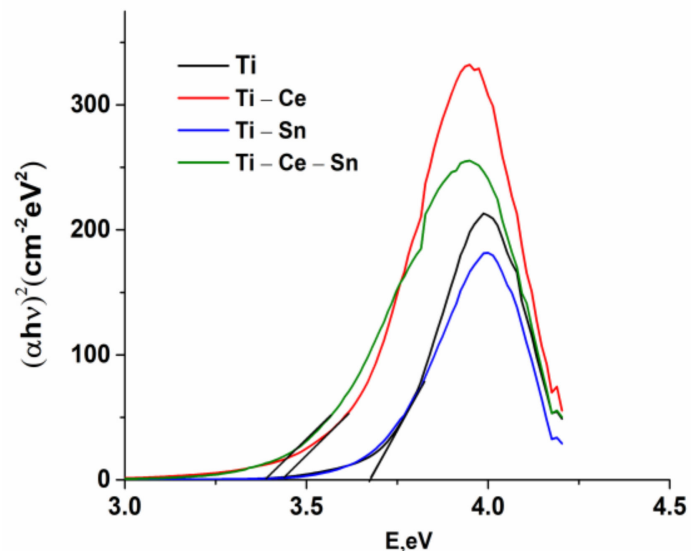

(b)

Figure 5. Absorbance data (a) and Tauc plot (b) for prepared films.

Table 2. Band gaps determined from UV-Vis spectra.

\begin{tabular}{cc}
\hline Sample & Band Gap \\
\hline (Ti) & 3.68 \\
$($ Ti-Ce) & 3.44 \\
$($ Ti-Sn) & 3.68 \\
$($ Ti-Ce-Sn) & 3.38 \\
\hline
\end{tabular}

\subsection{Photocatalytic Ozonation Tests}

Catalytic tests were performed for all prepared films using the following operational parameters: $\mathrm{pH}=7$, gas flow rate $=10 \mathrm{~L} / \mathrm{h}$, temperature $=20^{\circ} \mathrm{C}$, two or four catalytic slides, and two different $\mathrm{O}_{3}$ concentrations: 6 or $12 \mathrm{~g} / \mathrm{Nm}^{3}$ (equivalent to $1 \mathrm{mg} / \mathrm{min}$ and $2 \mathrm{mg} / \mathrm{min}$, respectively). For noncatalytic tests, bare glass slides were used. The reactions were repeated once with the same slides for verification of catalysts' reusability and, for all runs, a multiparametric assessment of the process was performed. Thus, several chemical species and parameters were monitored: paracetamol concentration, total organic carbon (TOC), solution absorbance at $254 \mathrm{~nm}$, ammonia ions, and nitrate ions. From the evolution of paracetamol normalized concentrations (Figure 6) it can be observed that for lower ozone input $\left(6 \mathrm{~g} / \mathrm{Nm}^{3}\right)$, the noncatalytic process occurs very slow compared with catalytic ones. With the increasing $\mathrm{O}_{3}$ concentration $\left(12 \mathrm{~g} / \mathrm{Nm}^{3}\right)$, the reaction rate for the noncatalytic process rose significantly and became comparable with catalytic tests performed with two catalytic slides (Figure 7a). However, when using four slides (Figure 7b), the oxidation of the pollutant occurs much more rapidly and the target compound is removed in less than $45 \mathrm{~min}$ for (Ti) and (Ti-Sn) systems and in nearly $90 \mathrm{~min}$ in absence of catalysts. The reusability of catalytic slides is proved for all systems by the same evolution of normalized paracetamol concentration for two consecutive reactions (Figures S2-S5, Supplementary Material). Monitoring the process only from the target pollutant perspective is not a good choice since the oxidation byproducts can also be toxic and require advanced removal. Thus, UV absorbance at $254 \mathrm{~nm}$ (UV254) for prelevated samples during the reactions is generally considered as an indicator of the presence of unsaturated carbon bonds (mostly from aromatic compounds) and is a useful monitoring tool [69-76]. Figure 8 shows that the evolution of the aromatic and/or double bond containing oxidation byproducts follows the same behavior such as the removal of the parent compound and is persistent throughout the entire reactions, especially for processes with a low ozone concentration of two catalytic slides. The reason for this is that the paracetamol molecule loses the acetamide group which is further transformed into ammonia ions. Moreover, the core of the molecule is more or less 
destroyed (depending on reaction conditions) by consecutive augmentation with oxygen, followed by cycle opening and subsequent transformation in smaller moieties [77-81]. Additionally, this parameter was used to verify the reusability of the catalytic system and it was found that for two consecutive reactions the activity remains unchanged (Figures S6-S9, Supplementary Material). The gradual destruction of pollutant molecules is the reason for the slow mineralization process, as can be observed from Figure $9 \mathrm{a}-\mathrm{c}$ where $\mathrm{TOC} / \mathrm{TOC}_{\mathrm{o}}$ evolution versus time is depicted. The elimination of organic carbon by mineralization is almost absent without catalysts at $6 \mathrm{~g} \mathrm{O}_{3} / \mathrm{Nm}^{3} \mathrm{~m}$ and, in the presence of a catalyst, the TOC removal attains 35\%. Doubling the ozone dose and using two catalyst slides lead to TOC elimination and up to $55 \%$ for (Ti) and $48 \%$ for (Ti-Ce-Sn) thin films, while for noncatalytic reaction, mineralization occurs up to $38 \%$. By using four catalytic slides, mineralization is improved up to $\sim 68 \%$ for all systems.

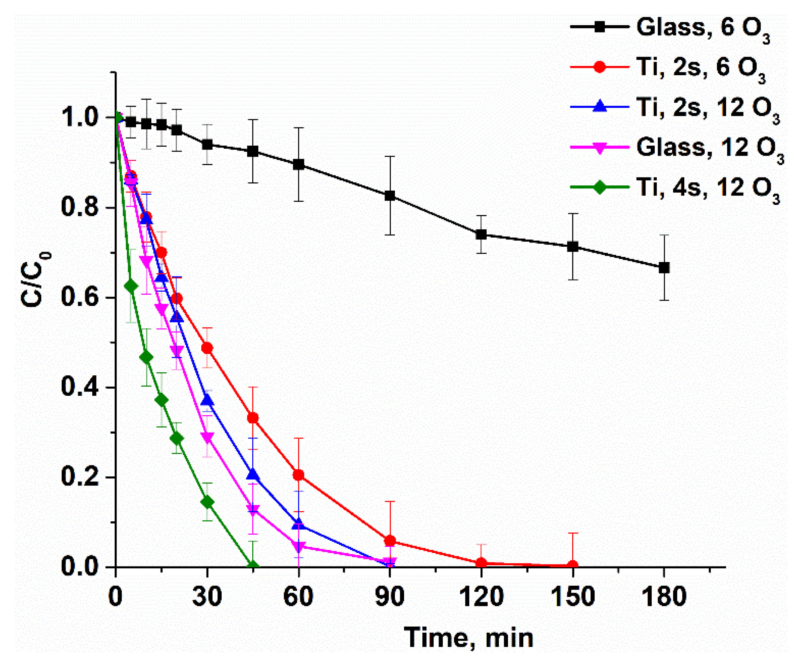

(a)

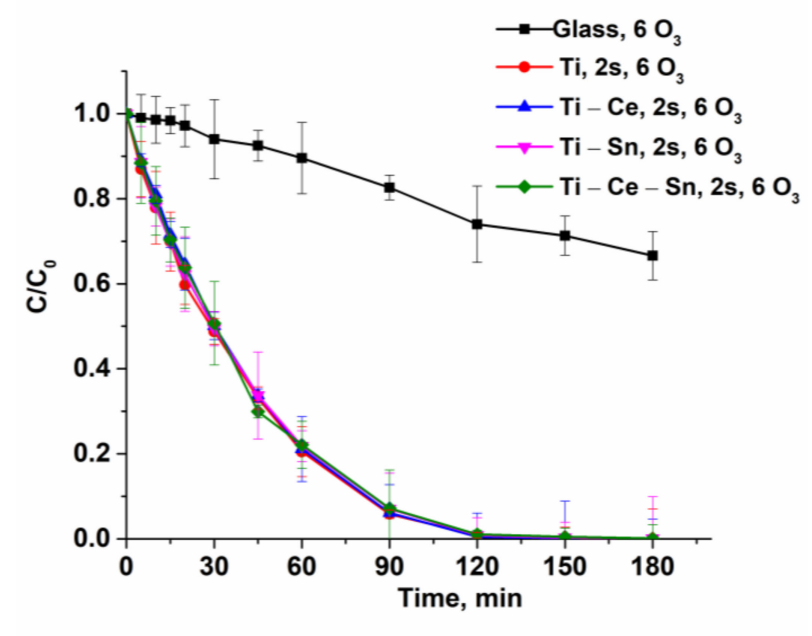

(b)

Figure 6. (a) Evolution of paracetamol normalized concentration during the oxidation process for (Ti) system at different ozone concentrations and number of slides; (b) Comparison of prepared catalytic systems at a lower ozone input and two slides.

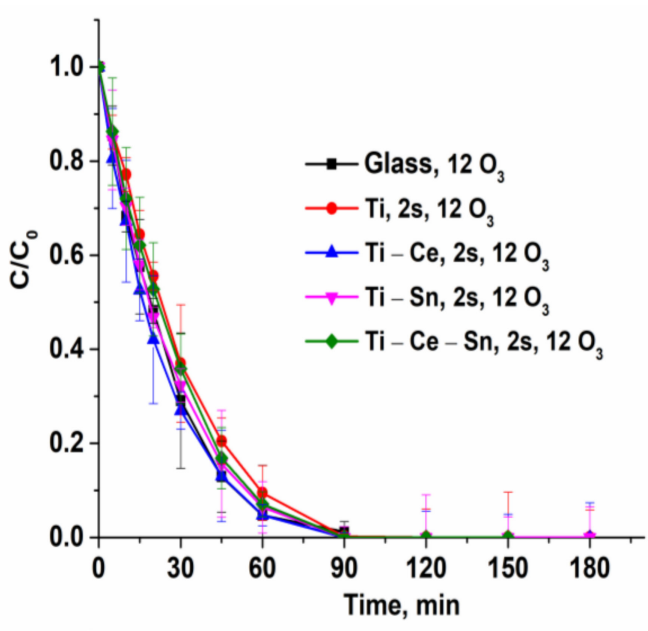

(a)

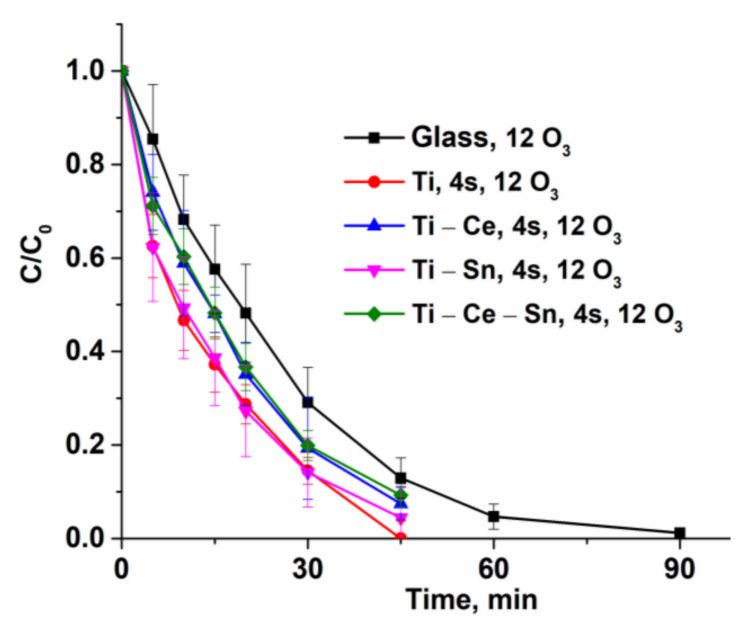

(b)

Figure 7. (a) Comparison of prepared catalytic systems at a higher ozone input and two slides; (b) Comparison of prepared catalytic systems at a higher ozone input and four slides. 


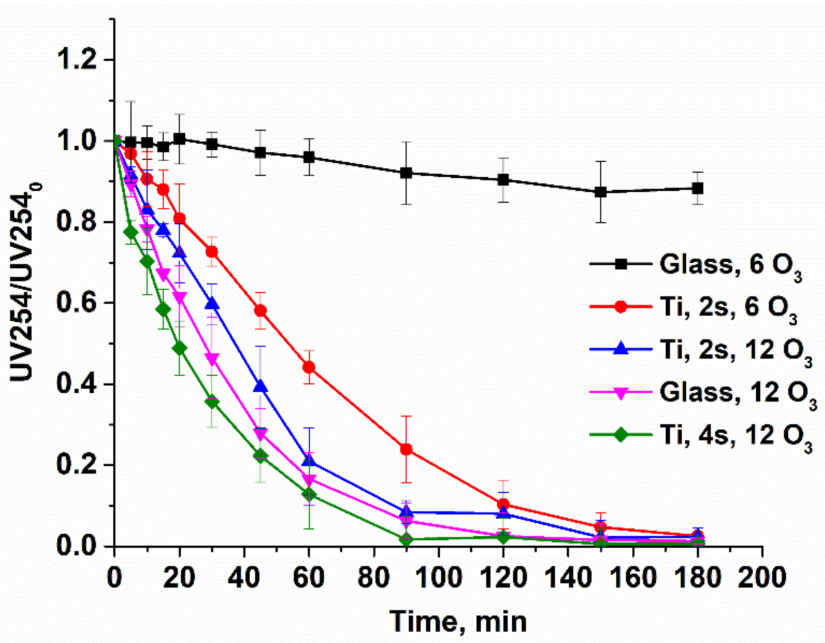

(a)

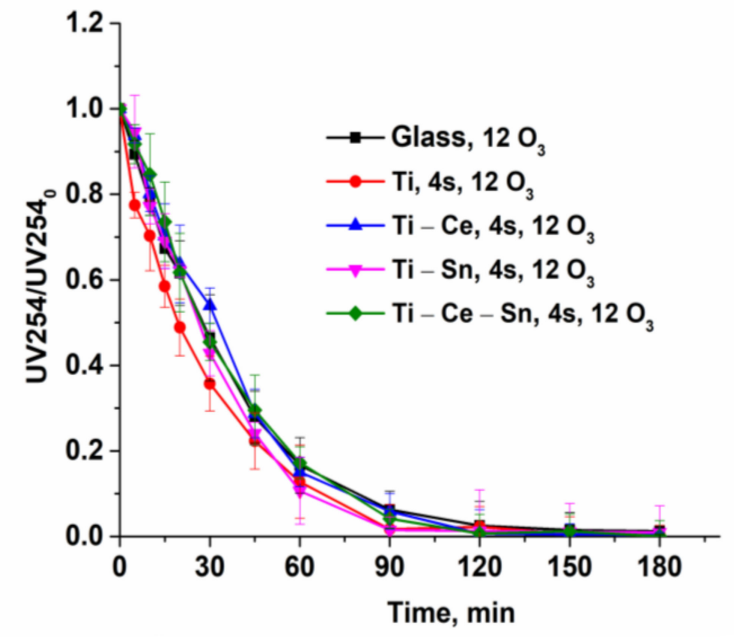

(b)

Figure 8. (a) Evolution of normalized UV254 parameter for (Ti) system in different reaction conditions; (b) Evolution of a normalized UV254 parameter for all prepared systems at a higher ozone input and four slides.

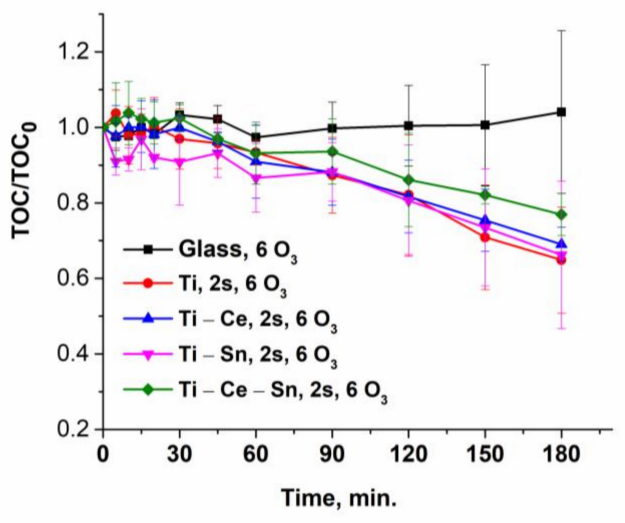

(a)

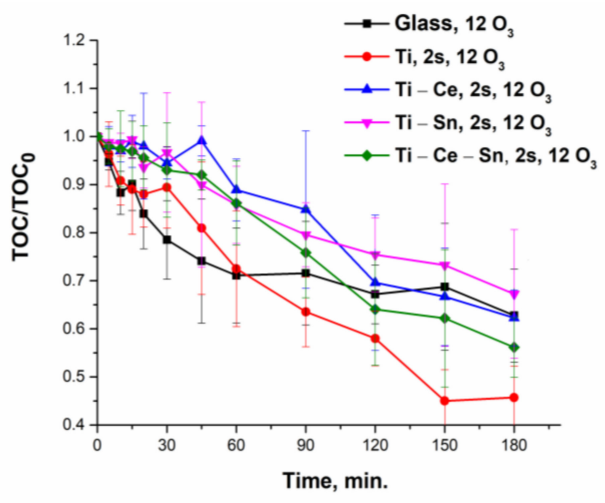

(b)

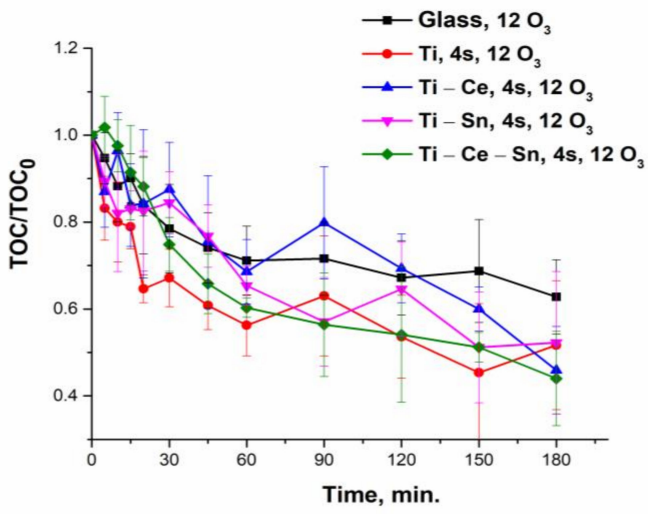

(c)

Figure 9. (a) Evolution of normalized TOC for all prepared systems at a lower ozone input and two slides; (b) Evolution of normalized TOC for all prepared systems at a higher ozone input and two slides; (c) Evolution of normalized TOC for all prepared systems at a higher ozone input and four slides. 
During the oxidation process besides the different organic molecules, another toxic and refractory pollutant is accumulated in the reaction system, namely, ammonia. Ammonia removal represents, in general, a significant challenge due to strict environmental regulations and, the main elimination route is by biological processes which require some demanding conditions to be applied (high capital costs, difficult process monitoring, large to medium effluents volumes, etc.) [82,83]. Catalytic ozonation, due to its flexibility as a process, can overcome these issues and eliminate the noxious ions. The only concern is the formation of nitrate ions but, in this case, the maximum concentration limit is significantly higher than those for ammonia. Hence, from Figure 10a-c presenting the ammonia build-up and subsequent removal, and Figure $11 \mathrm{a}-\mathrm{c}$, which shows the formation of nitrate ions, it can be observed that the presence of prepared catalytic systems can eliminate the toxic ions. Thus, for a lower ozone concentration, the amount of ammonia released during the noncatalytic test is much smaller compared to all catalytic systems since the overall process is very slow (not only for ammonia). By doubling the ozone concentration and in absence of a catalyst, the outcome is a higher accumulation of ammonia until some point where the concentration reaches a plateau. On the contrary, for prepared thin films regardless of the number of slides used and ozone concentration, the ammonia is oxidized at a rapid pace, as can be detected from the nitrate formation. However, the most active systems for ammonia removal are (Ti) and (Ti-Ce-Sn).

\subsubsection{Ozone Consumption}

Ozone consumption is an important parameter that governs the efficiency of the process from an economical perspective. Using an online analyzer is a much easier and accurate method to obtain the real ozone consumption compared with the iodometric approach. During a reaction, the amount of ozone that enters the reactor is not entirely consumed and, the residual ozone is lost without the possibility of being recovered. Hence, the main objectives in the oxidation processes are using in large amounts the reactants, and completely removing the organic matter. From Figure $12 \mathrm{a}-\mathrm{c}$ and Table 3, it can be observed that ozone is efficiently used in the presence of catalysts, even for lower input concentrations of the oxidant agent compared with not-catalytic processes. These values were obtained by integrating the area below the ozone evolution curve using Origin lab software. Additionally, it can be noticed that in terms of TOC removal, (Ti-Ce) and (Ti-Ce$\mathrm{Sn}$ ) are the most effective systems with 36.33 and $39.53 \mathrm{mg} \mathrm{O} / \mathrm{mg}$ TOC (for 4 slides) or 15.21 and $12.72 \mathrm{mg} \mathrm{O}_{3} / \mathrm{mg}$ TOC removed (for 2 slides).

Table 3. Ozone consumption during the oxidation process for prepared thin films in different conditions.

\begin{tabular}{|c|c|c|c|c|c|}
\hline $\begin{array}{c}\text { Catalytic } \\
\text { System/Ozone } \\
\text { Concentration }\end{array}$ & $\begin{array}{l}\text { Consumed } \\
\text { Ozone (mg) }\end{array}$ & $\begin{array}{l}\text { Residual Ozone } \\
\text { (mg) }\end{array}$ & $\begin{array}{l}\text { Ozone Input } \\
\text { (mg) }\end{array}$ & $\begin{array}{l}\mathrm{mgO}_{3} / \mathrm{mg} \text { TOC Removed } \\
\text { (Consumed Ozone) }\end{array}$ & $\begin{array}{c}\mathrm{mgO}_{3} / \mathrm{mg} \text { TOC } \\
\text { Removed } \\
\text { (Ozone Input) }\end{array}$ \\
\hline Glass, $12 \mathrm{O}_{3}$ & 261.38 & 98.62 & 360 & 54.10 & 74.51 \\
\hline $\mathrm{Ti}, 4 \mathrm{~s}, 12 \mathrm{O}_{3}$ & 341.85 & 18.15 & 360 & 48.88 & 51.48 \\
\hline Ti-Ce, $4 \mathrm{~s}, 12 \mathrm{O}_{3}$ & 254.86 & 105.14 & 360 & 36.44 & 51.48 \\
\hline Ti-Sn, $4 \mathrm{~s}, 12 \mathrm{O}_{3}$ & 290.01 & 69.99 & 360 & 47.52 & 58.98 \\
\hline Ti-Ce-Sn, $4 \mathrm{~s}, 12 \mathrm{O}_{3}$ & 286.53 & 73.47 & 360 & 39.53 & 49.67 \\
\hline $\mathrm{Ti}, 2 \mathrm{~s}, 12 \mathrm{O}_{3}$ & 324.45 & 35.55 & 360 & 45.57 & 50.56 \\
\hline Ti-Ce, $2 \mathrm{~s}, 12 \mathrm{O}_{3}$ & 343.54 & 16.46 & 360 & 67.54 & 70.78 \\
\hline Ti-Sn, 2s, $12 \mathrm{O}_{3}$ & 327.26 & 32.74 & 360 & 77.99 & 85.80 \\
\hline Ti-Ce-Sn, 2s, $12 \mathrm{O}_{3}$ & 342.22 & 17.78 & 360 & 61.17 & 64.35 \\
\hline Glass, $6 \mathrm{O}_{3}$ & 157.34 & 22.66 & 180 & 412.47 & 471.88 \\
\hline $\mathrm{Ti}, 2 \mathrm{~s}, 6 \mathrm{O}_{3}$ & 160.72 & 19.28 & 180 & 33.26 & 37.25 \\
\hline $\mathrm{Ti}-\mathrm{Ce}, 2 \mathrm{~s}, 6 \mathrm{O}_{3}$ & 164.79 & 15.21 & 180 & 40.50 & 44.24 \\
\hline Ti-Sn, $2 \mathrm{~s}, 6 \mathrm{O}_{3}$ & 155.56 & 24.44 & 180 & 33.98 & 39.32 \\
\hline Ti-Ce-Sn, 2s, $6 \mathrm{O}_{3}$ & 167.28 & 12.72 & 180 & 54.82 & 58.98 \\
\hline
\end{tabular}




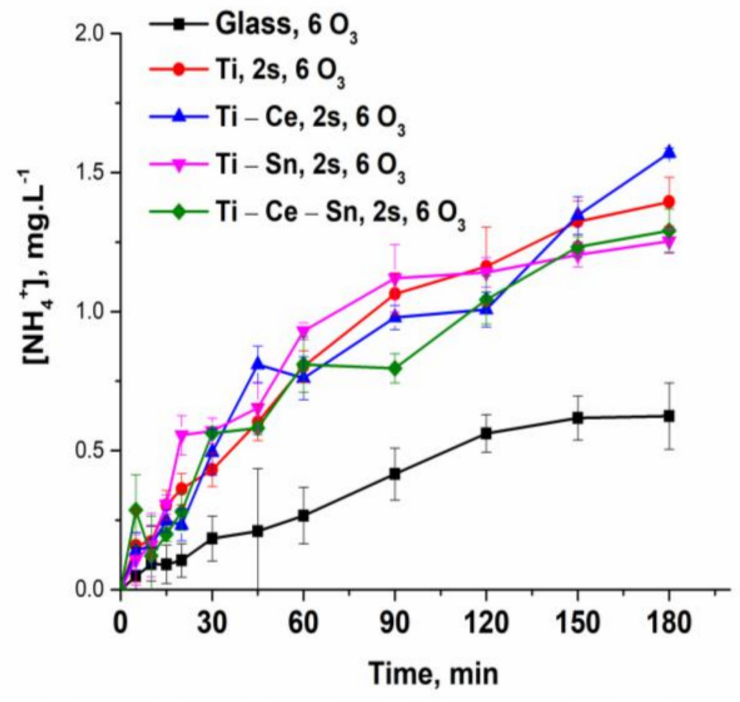

(a)

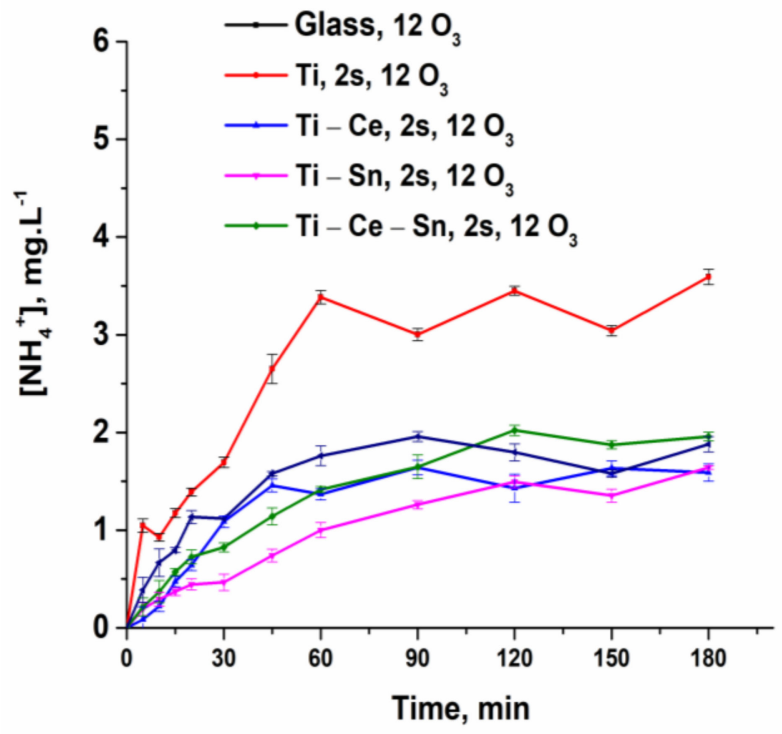

(b)

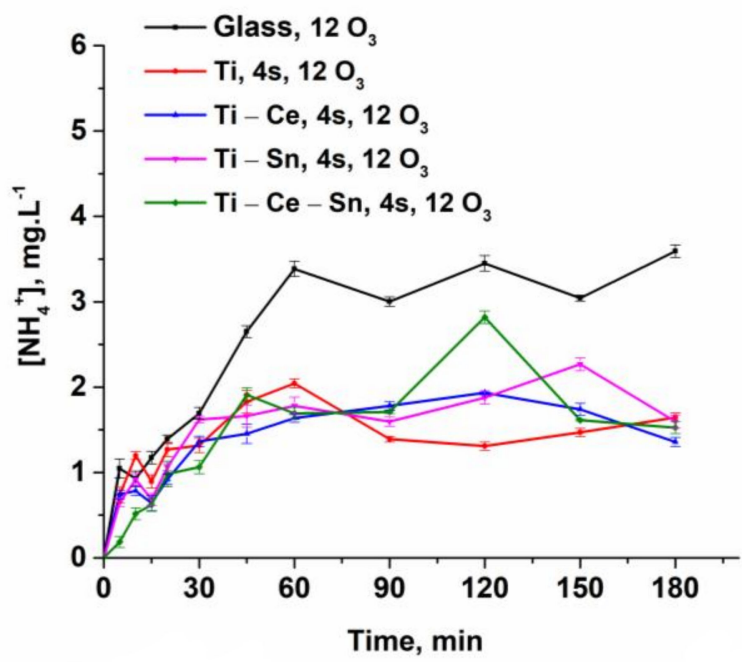

(c)

Figure 10. (a) Evolution of ammonia ions for all prepared systems at a lower ozone input and two slides; (b) Evolution of ammonia ions for all prepared systems at a higher ozone input and two slides; (c) Evolution of ammonia ions for all prepared systems at a higher ozone input and four slides. 


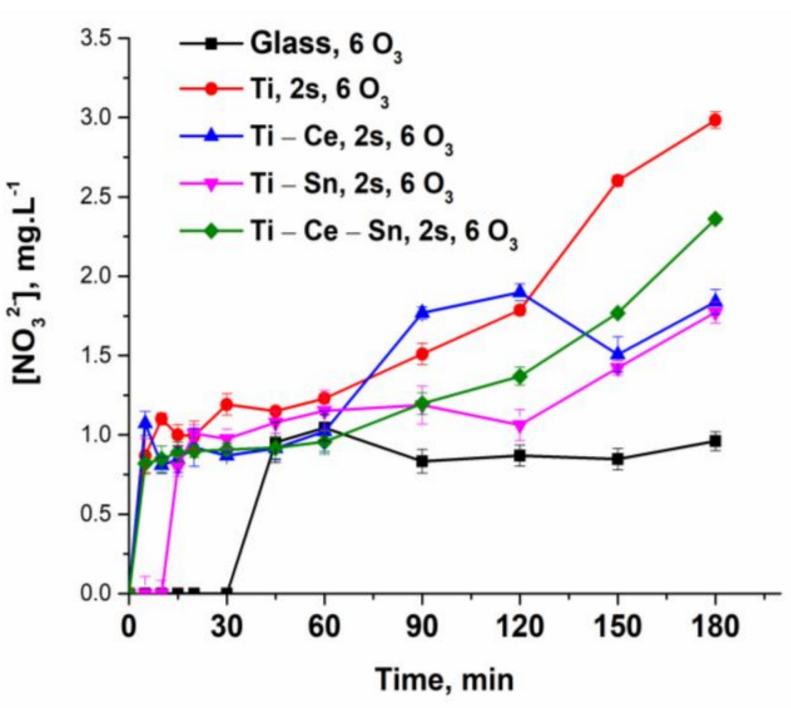

(a)

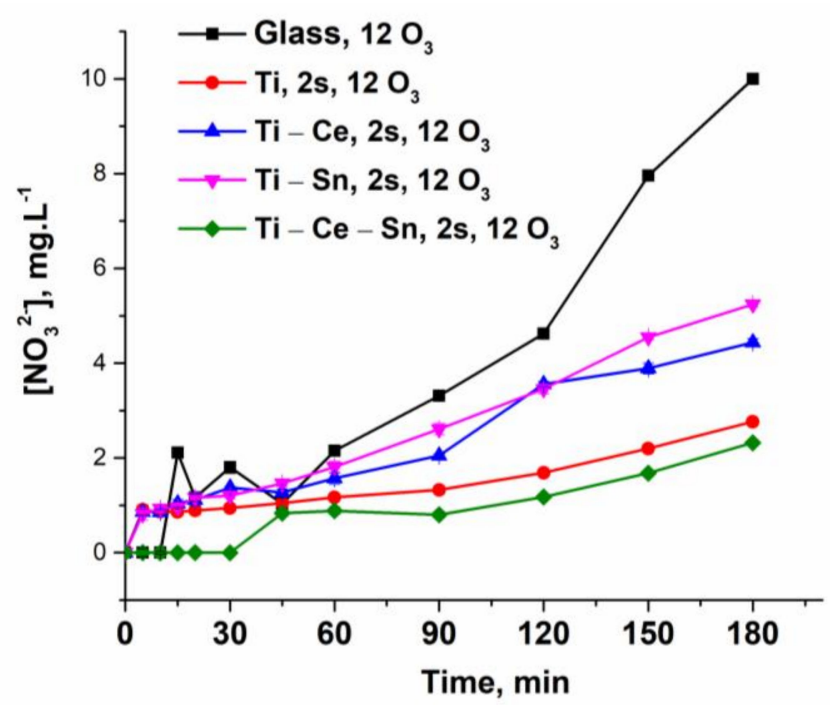

(b)

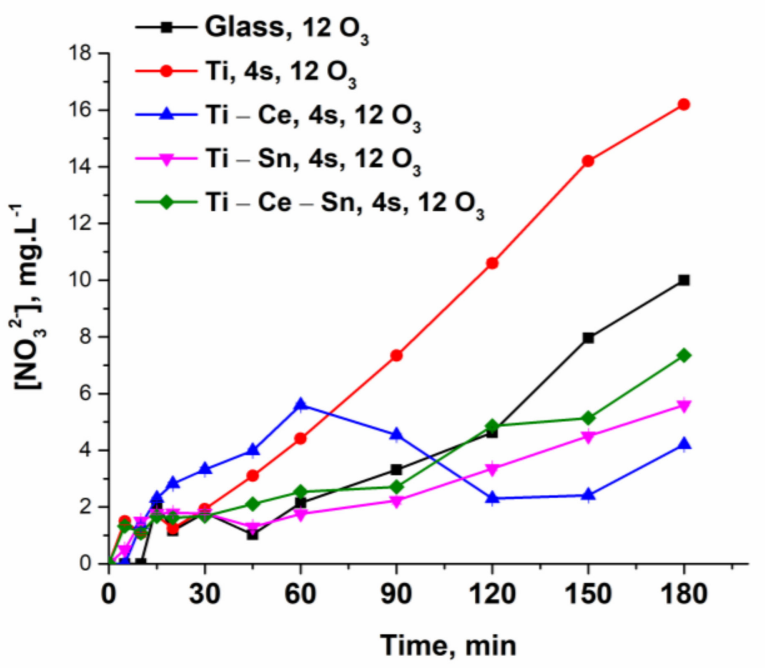

(c)

Figure 11. (a) Evolution of nitrate ions for all prepared systems at a lower ozone input and two slides; (b) Evolution of nitrate ions for all prepared systems at a higher ozone input and two slides; (c) Evolution of nitrate ions for all prepared systems at a higher ozone input and four slides. 


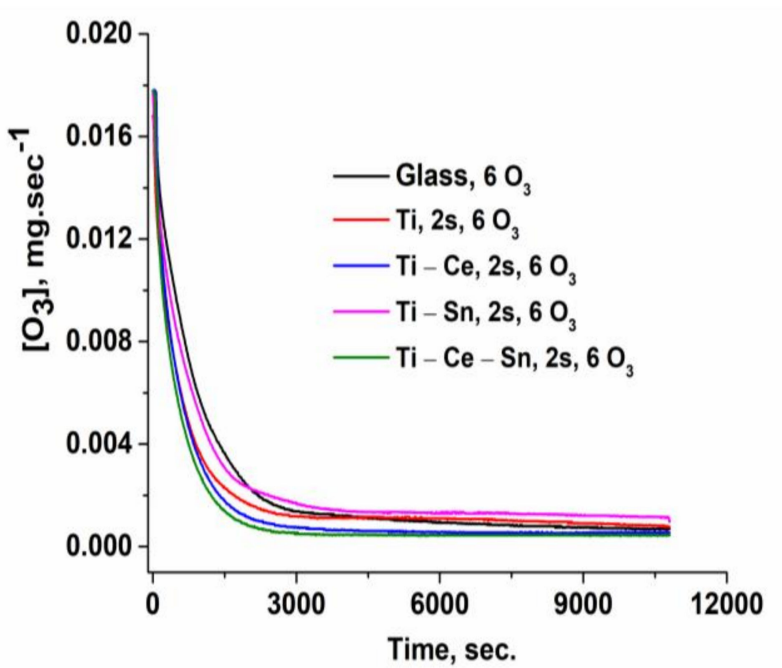

(a)

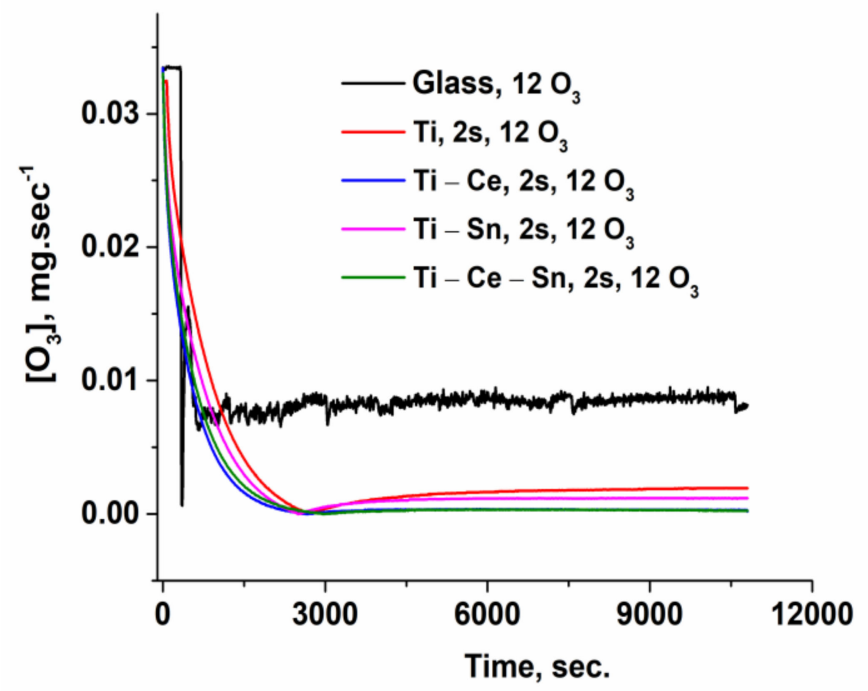

(b)

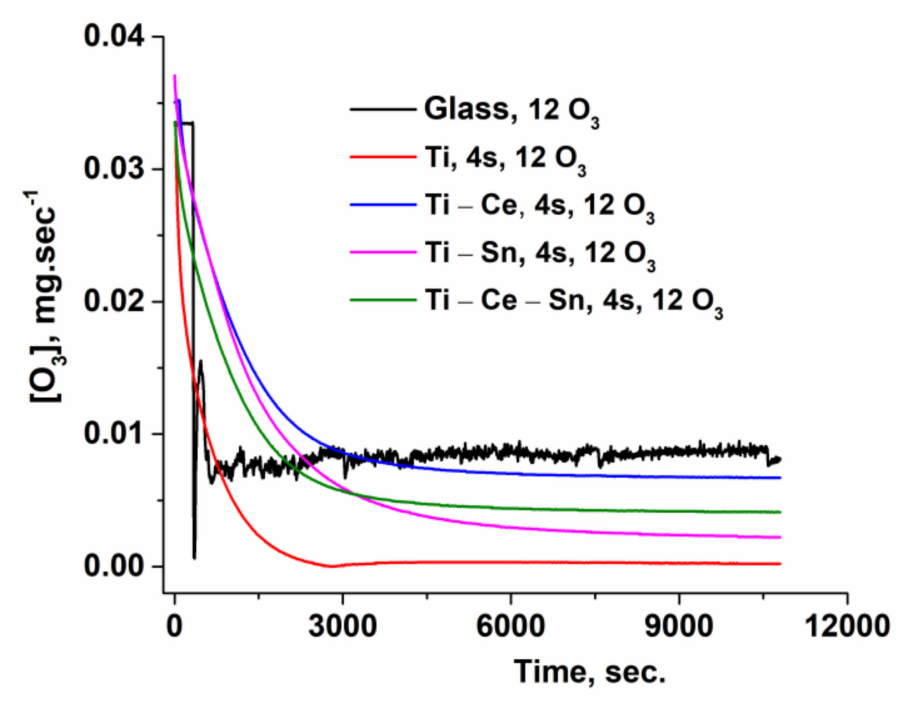

(c)

Figure 12. (a) Ozone concentration evolution in time for a lower ozone input and two slides; (b) Ozone concentration evolution in time for a higher ozone input and two slides; (c) Ozone concentration evolution in time for a higher ozone input and four slides.

\subsubsection{Kinetic Study}

Paracetamol $(\mathrm{Pa})$ ozonation in the presence and absence of catalysts can be modeled by a pseudo-first-order kinetic (Equations (2)-(4)) where $k_{1}$ and $k_{2}$ are the reaction rate constants of pollutant interaction with ozone and $\mathrm{OH} \bullet$ respectively. By plotting $\ln [\mathrm{Pa}] /[\mathrm{Pa}]_{\mathrm{o}}$ versus time (Equation (5), Figure 13a-c), the observed constants ( $k_{o b s c a t}$ and $k_{o b s}$ not-cat) will be obtained and are presented in Table 4 . The values of the kinetic constants are used as indicators for comparing the performances of catalytic and not-catalytic processes. It can be observed that most active systems are (Ti) and (Ti-Ce-Sn) since their removal rate constant of paracetamol are 1.5 and 1.53 times, respectively, higher than that of the noncatalytic process.

$$
-\frac{d[\mathrm{~Pa}]}{d t}=k_{1}\left[\mathrm{O}_{3}\right][\mathrm{Pa}]+k_{2}\left[\mathrm{OH} \bullet[\mathrm{Pa}]=k_{\text {obs cat }}[\mathrm{Pa}]\right.
$$




$$
\begin{gathered}
\mathrm{O}_{3}+\text { Catalyst active sites } \rightarrow \mathrm{OH} \bullet \\
-\frac{d[\mathrm{~Pa}]}{d t}=k_{1}\left[\mathrm{O}_{3}\right][\mathrm{Pa}]=k_{\text {obs not-cat }}[\mathrm{Pa}] \\
\ln \left(\frac{[\mathrm{Pa}]}{[\mathrm{Pa}]_{0}}\right)=-k_{\text {obs }} t
\end{gathered}
$$

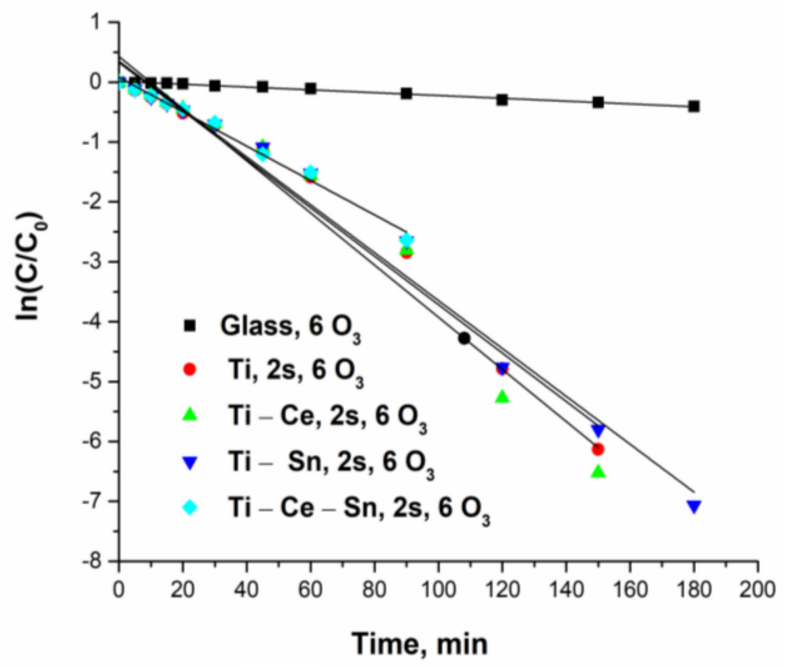

(a)

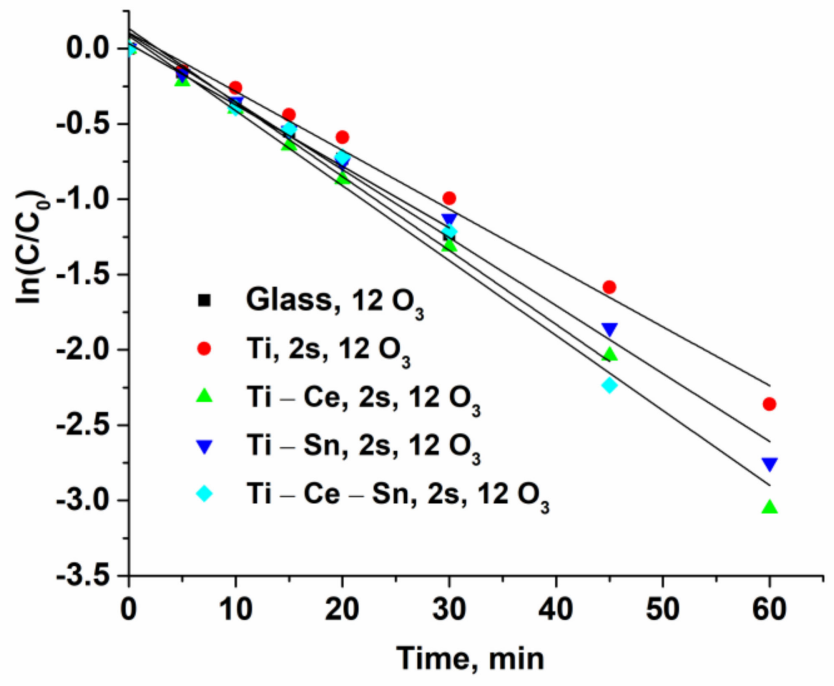

(b)

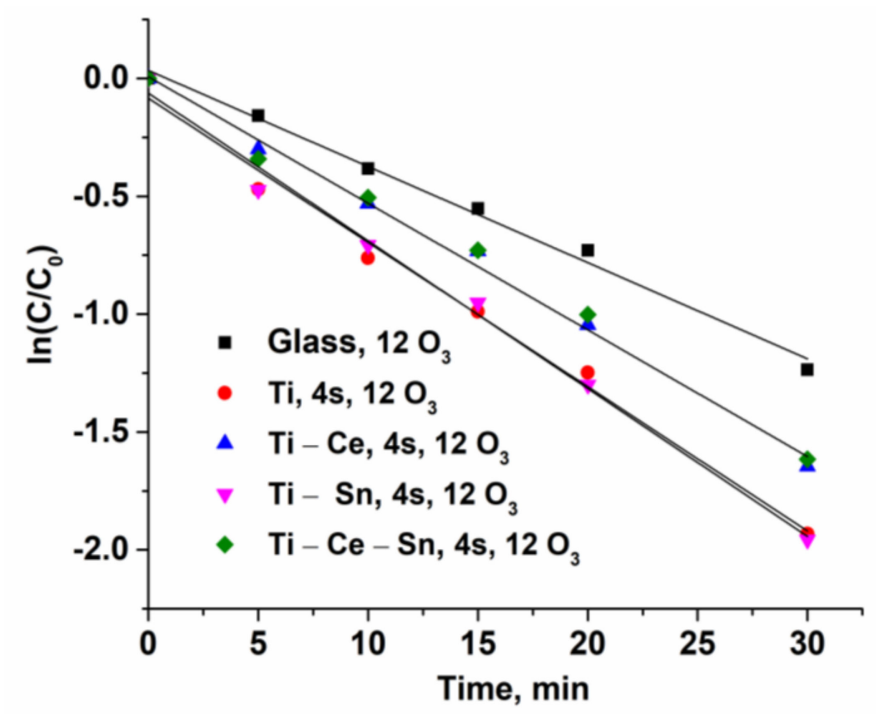

(c)

Figure 13. (a) Pseudo-first-order plots of $\ln \left(C / C_{o}\right)$ lower ozone input and two slides; (b) Pseudo-firstorder plots of $\ln \left(\mathrm{C} / \mathrm{C}_{\mathrm{o}}\right)$ higher ozone input and two slides; (c) Pseudo-first-order plots of $\ln \left(\mathrm{C} / \mathrm{C}_{\mathrm{o}}\right)$ higher ozone input and four slides. 
Table 4. Kinetic parameters for the paracetamol oxidation in different experimental conditions.

\begin{tabular}{ccc}
\hline Catalytic System/Ozone Concentration & $\boldsymbol{k}_{\text {obs }}\left(\mathbf{m i n}^{\mathbf{- 1}}\right) \mathbf{1 0}^{\mathbf{2}}$ & $\boldsymbol{R}^{\mathbf{2}}$ \\
\hline $\mathrm{Glass}, 12 \mathrm{O}_{3}$ & 4.07 & 0.9913 \\
$\mathrm{Ti}, 4 \mathrm{~s}, 12 \mathrm{O}_{3}$ & 6.12 & 0.98778 \\
$\mathrm{Ti}-\mathrm{Ce}, 4 \mathrm{~s}, 12 \mathrm{O}_{3}$ & 5.37 & 0.99401 \\
$\mathrm{Ti}-\mathrm{Sn}, 4 \mathrm{~s}, 12 \mathrm{O}_{3}$ & 6.26 & 0.99085 \\
$\mathrm{Ti}-\mathrm{Ce}-\mathrm{Sn}, 4 \mathrm{~s}, 12 \mathrm{O}_{3}$ & 5.19 & 0.98929 \\
$\mathrm{Ti}, 2 \mathrm{~s}, 12 \mathrm{O}_{3}$ & 3.90 & 0.98754 \\
$\mathrm{Ti}-\mathrm{Ce}, 2 \mathrm{~s}, 12 \mathrm{O}_{3}$ & 4.97 & 0.99081 \\
$\mathrm{Ti}-\mathrm{Sn}, 2 \mathrm{~s}, 12 \mathrm{O}_{3}$ & 4.51 & 0.98938 \\
$\mathrm{Ti}-\mathrm{Ce}-\mathrm{Sn}, 2 \mathrm{~s}, 12 \mathrm{O}_{3}$ & 4.91 & 0.9672 \\
$\mathrm{Glass}, 6 \mathrm{O}_{3}$ & 0.23 & 0.99029 \\
$\mathrm{Ti}, 2 \mathrm{~s}, 6 \mathrm{O}_{3}$ & 4.04 & 0.97132 \\
$\mathrm{Ti}-\mathrm{Ce}, 2 \mathrm{~s}, 6 \mathrm{O}_{3}$ & 4.35 & 0.95859 \\
$\mathrm{Ti}-\mathrm{Sn}, 2 \mathrm{~s}, 6 \mathrm{O}_{3}$ & 3.99 & 0.98008 \\
Ti-Ce-Sn, 2s, $6 \mathrm{O}_{3}$ & 2.87 & 0.98847 \\
\hline
\end{tabular}

\subsubsection{Photocatalytic Mechanism}

Photocatalytic ozonation of different pollutants generally involves several steps and routes $[24,84-90]$. In this study, from the reactions at small ozone concentration $\left(6 \mathrm{O}_{3}\right)$, it can be observed that direct oxidation with ozone (Figure 14A) has low importance (Equations (6) and (7)), while at a higher ozone concentration $\left(12 \mathrm{O}_{3}\right)$ and in the presence of UV radiation (Figure 14B), the radical production increases significantly (Equations (8)-(10)). In the presence of catalysts, several processes occur. The process starts with electrons transfer from the valence band to the conduction band as a result of radiation excitation. Thus, the formed electrons and holes are available for interaction with $\mathrm{O}_{3}$ and $\mathrm{OH}^{-}{ }^{-}$(s) (Figure 14C,E) (Equations (11)-(16)). All prepared catalytic systems can perform this step as resulted from experimental data These radicals represent the core of the process by performing the oxidation of paracetamol molecules and leading to complete mineralization of organic substrate (Equations (17) and (18)). As already stated, ammonia is a refractory to oxidation pollutant therefore, require significant amount of radical species depending on reaction conditions [89]. However it can be observed that catalytic systems are able to sustain several parallel processes and eliminating the toxic compounds like ammonia (Figure 14F). Mixed components thin films present some properties which can improve their catalytic activity. Hence in case of (Ti-Sn) system the photogenerated electrons from $\mathrm{TiO}_{2}$ conduction band migrate into the $\mathrm{SnO}_{2}$ conduction band while formed holes migrate backwards (Equations (19) and (20)) [90]. This is an important step in delaying the recombination of electrons and holes. In case of (Ti-Ce) system two significant phenomena occur: on $\mathrm{CeO}_{2}$ oxide surface some oxygen vacancies are formed through interaction with oxygen species from gas/liquid phase and a redox couple $\mathrm{Ce}^{3+} / \mathrm{Ce}^{4+}$ (Figure 14D) is formed [91,92]. Furthermore, $\mathrm{Ce}^{3+}$ is able to generate radicalic species in a similar manner with electrons from the conductive band (Equations (21) and (22)); a transfer of electrons from $\mathrm{CeO}_{2}$ also occursconduction band to $\mathrm{TiO}_{2}$ conduction band since bandgap energy of $\mathrm{CeO}_{2}$ is situated at more negative values $(-0.37 \mathrm{eV})$ than those of $\mathrm{TiO}_{2}(-0.24 \mathrm{eV})$ while holes migrate in opposite directions (Equations (23) and (24)) [92]. Hence, (Ti-Ce-Sn) system apart from a slower recombination of charges may be subject to electron agglomeration in $\mathrm{SnO}_{2}$ conduction band and of holes in $\mathrm{CeO}_{2}$ valence band. 


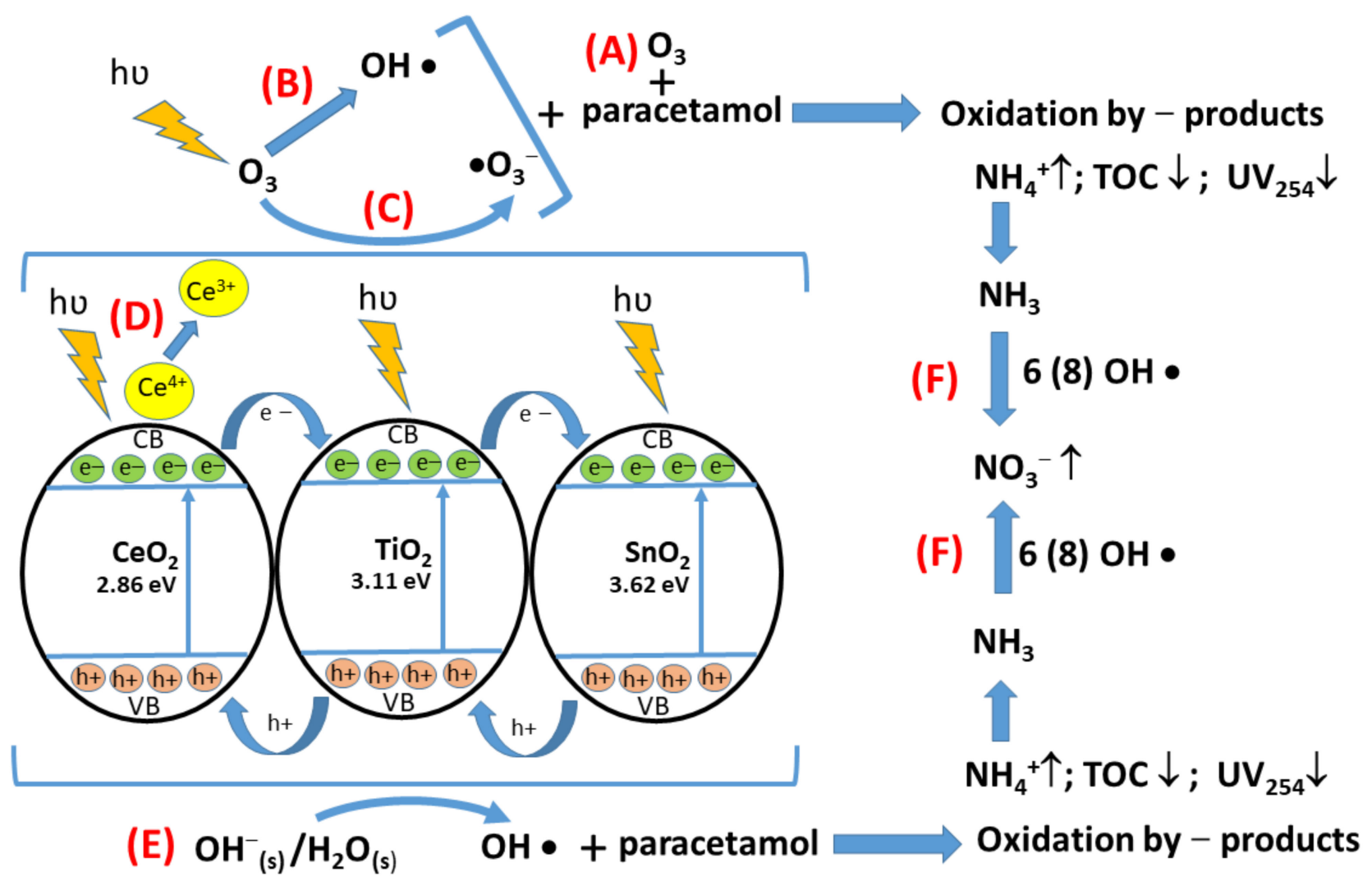

Figure 14. Proposed photocatalytic mechanism for paracetamol oxidation; occurring processes: direct oxidation with ozone (A); radical production in the presence of UV radiation (B); interactions of formed electrons and holes with $\mathrm{O}_{3}$ and $\mathrm{OH}(\mathbf{C}, \mathbf{E}) ; \mathrm{Ce}^{3+} / \mathrm{Ce}^{4+}$ formation (D), $\mathrm{NH}_{3}$ oxidation (F).

$\mathrm{O}_{3}$ direct reactions:

$$
\begin{gathered}
\mathrm{O}_{3}+\mathrm{Pa} \rightarrow \text { Oxidation by }- \text { products } \\
\mathrm{O}_{3} \rightarrow \mathrm{O}_{2}+\mathrm{O}(1 D)
\end{gathered}
$$

$\mathrm{O}_{3} / \mathrm{UV}$ reactions:

$$
\begin{gathered}
\mathrm{O}_{3}+h v(254 n m) \rightarrow \mathrm{O}_{2}+\mathrm{O}(1 \mathrm{D}) \\
\mathrm{O}(1 \mathrm{D})+\mathrm{H}_{2} \mathrm{O} \rightarrow \mathrm{H}_{2} \mathrm{O}_{2}+2 \mathrm{OH} \bullet \\
\mathrm{OH} \bullet+\mathrm{Pa} \rightarrow \text { Oxidation by }- \text { products }
\end{gathered}
$$

$\mathrm{O}_{3} / \mathrm{UV} /$ catalyst reactions:

$$
\begin{gathered}
h v+\mathrm{TiO}_{2} \rightarrow h^{+}+e^{-} \\
\mathrm{OH}_{(s)}^{-}+h^{+} \rightarrow \mathrm{OH} \bullet \\
\mathrm{H}_{2} \mathrm{O}_{(s)}+h^{+} \rightarrow \mathrm{H}^{+}+\mathrm{OH} \bullet \\
\mathrm{O}_{3}+e^{-} \rightarrow \mathrm{O}_{3}^{-} \bullet \\
\mathrm{O}_{3}^{-} \bullet+\mathrm{H}^{+} \rightarrow \mathrm{HO}_{3} \\
\mathrm{HO}_{3} \bullet \mathrm{OH} \bullet+\mathrm{O}_{2} \\
h^{+} / \mathrm{OH} \bullet / \mathrm{O}(\mathrm{DD})+\mathrm{Pa} \rightarrow \mathrm{Oxidation} \text { by }- \text { products } \\
e^{-}+\mathrm{Pa} \rightarrow \mathrm{Reduction} \text { by }- \text { products }
\end{gathered}
$$




$$
\begin{gathered}
\mathrm{TiO}_{2} / \mathrm{SnO}_{2}+h v \rightarrow \mathrm{TiO}_{2}\left(h^{+}+e^{-}\right) / \mathrm{SnO}_{2}\left(h^{+}+e^{-}\right) \\
\mathrm{TiO}_{2}\left(h^{+}+e^{-}\right) / \mathrm{SnO}_{2}\left(h^{+}+e^{-}\right) \rightarrow \mathrm{TiO}_{2}\left(h^{+}\right) / \mathrm{SnO}_{2}\left(e^{-}\right) \\
\mathrm{C} e^{4+}+e^{-} \rightarrow \mathrm{Ce}^{3+} \\
\mathrm{O}_{3}+\mathrm{Ce}^{3+} \rightarrow \mathrm{C} e^{4+}+\mathrm{O}_{3}^{-} \bullet \\
\mathrm{TiO}_{2} / \mathrm{CeO}_{2}+h v \rightarrow \mathrm{TiO}_{2}\left(h^{+}+e^{-}\right) / \mathrm{CeO}_{2}\left(h^{+}+e^{-}\right) \\
\mathrm{TiO}_{2}\left(h^{+}+e^{-}\right) / \mathrm{CeO}_{2}\left(h^{+}+e^{-}\right) \rightarrow \mathrm{TiO}_{2}\left(e^{-}\right) / \mathrm{CeO}_{2}\left(h^{+}\right)
\end{gathered}
$$

\section{Conclusions}

For several years, catalytic ozonation represents an important alternative for water treatment. Therefore, intensive work was made in order to improve this process. In this study, paracetamol (a widely used NSAID) catalytic ozonation using $\mathrm{TiO}_{2}-\mathrm{Me}_{\mathrm{x}} \mathrm{O}_{\mathrm{y}}$ thin films was investigated. Using thin film in the oxidation removal of pollutants represents an important step for enhancement for this type of process and, in addition, to its simplification by avoiding the difficult step of catalyst separation. The present study describes for the first time in literature, the removal of paracetamol from aqueous solutions using thin films catalysts based on $\mathrm{TiO}_{2}-\mathrm{Me}_{\mathrm{x}} \mathrm{O}_{\mathrm{y}}$ nanosystems deposited on glass plates and immersed into a semi-batch reactor; the prepared thin films being very active in eliminating the targeted compound.

Considering that the initial concentration of the pollutant selected for this study is much higher compared with real-world effluents, the obtained results are very encouraging, giving the prospect of the complete elimination of the pollutants from aqueous effluents regardless of the compound type. The relative performances of noncatalytic processes can be attributed mainly to the presence of UV radiation since it is well-known that ozonation alone cannot cope with some resistance to oxidation chemical species. The higher than usual input concentrations represent a successful endurance test for the prepared catalytic systems.

Supplementary Materials: The following supporting information can be downloaded at: https:/ /www. mdpi.com/article/10.3390/nano12040613/s1, Figure S1: FTIR spectra of prepared film before and after use in oxidation reaction; Figure S2: Evolution of paracetamol normalized concentration during the oxidation process for (Ti) system for two successive cycles at lower ozone concentrations and 2 number of slides; Figure S3: Evolution of paracetamol normalized concentration during the oxidation process for (Ti-Ce) system for two successive cycles at lower ozone concentrations and 2 number of slides; Figure S4: Evolution of paracetamol normalized concentration during the oxidation process for (Ti-Sn) system for two successive cycles at lower ozone concentrations and 2 number of slides; Figure S5: Evolution of paracetamol normalized concentration during the oxidation process for (Ti-Ce-Sn) system for two successive cycles at lower ozone concentrations and 2 number of slides; Figure S6: Evolution of normalized UV254 parameter during the oxidation process for (Ti) system for two successive cycles at lower ozone concentrations and 2 number of slides; Figure S7: Evolution of normalized UV254 parameter during the oxidation process for (Ti-Ce) system for two successive cycles at lower ozone concentrations and 2 number of slides; Figure S8: Evolution of normalized UV254 parameter during the oxidation process for (Ti-Ce) system for two successive cycles at lower ozone concentrations and 2 number of slides; Figure S9: Evolution of normalized UV254 parameter during the oxidation process for (Ti-Ce) system for two successive cycles at lower ozone concentrations and 2 number of slides.

Author Contributions: Conceptualization, S.M.A., I.F., R.C.F. and A.D.; methodology, S.M.A., R.C.F. and A.D.; validation, S.M.A., I.F. and R.C.F.; investigation, S.M.A., R.I.B., A.V.N., C.B., E.A.O., M.N.V. and S.U.; resources, S.M.A., I.F., R.C.F. and S.U.; data curation, S.M.A., I.F. and R.C.F.; writingoriginal draft preparation, S.M.A., I.F., R.C.F. and A.D.; writing-review and editing, S.M.A., I.F., R.C.F. and A.D.; visualization, S.M.A. and I.F.; supervision, S.M.A., I.F. and R.C.F.; project administration, S.M.A., I.F. and S.U.; funding acquisition, S.M.A., I.F. and S.U. All authors have read and agreed to the published version of the manuscript. 
Funding: This research was funded through a grant from the Romanian National Authority for Scientific Research and Innovation, CNCS/CCCDI-UEFISCDI, project GreenCatOx, project code PNIII-P2-2.1-PED-2019-3166, contract 299/2020, within PNCDI III. IF, RCF and RIB also acknowledge the financial support of the Romanian Ministry of Research and Innovation, MCI (Ministry of Research, Innovation, and Digitization, MCID) through INCDCP ICECHIM Bucharest 2019-2022 Core Program PN. 19.23-Chem-Ergent, Project No.19.23.03. The APC was funded by project GreenCatOx, project code PN-III-P2-2.1-PED- 2019-3166, contract 299/2020, within PNCDI III.

Institutional Review Board Statement: Not applicable.

Informed Consent Statement: Not applicable.

Data Availability Statement: All data are available upon reasonable request from the authors.

Conflicts of Interest: The authors declare no conflict of interest.

\section{References}

1. Santos, L.; Araújo, A.N.; Fachini, A.; Pena, A.; Delerue-Matos, C.; Montenegro, M. Ecotoxicological Aspects Related to the Presence of Pharmaceuticals in the Aquatic Environment. J. Hazard. Mat. 2009, 175, 45-95. [CrossRef] [PubMed]

2. Persson, M.; Sabelström, E.; Gunnarsson, B. Handling of unused prescription drugs—Knowledge, behaviour and attitude among Swedish people. Environ. Int. 2008, 35, 771-774. [CrossRef] [PubMed]

3. Li, D.; Yang, M.Y.; Hu, J.; Ren, L.; Zhang, Y.; Li, K. Determination and fate of oxytetracycline and related compounds in oxytetracycline production wastewater and the receiving river. Environ. Toxicol. Chem. 2008, 27, 80-86. [CrossRef] [PubMed]

4. Gomez Ramos, M.J.; Petrovic, M.; Fernández-Alba, A.; Barcelo, D. Determination of Pharmaceuticals of Various Therapeutic Classes by Solid-Phase Extraction and Liquid Chromatography-Tandem Mass Spectrometry Analysis in Hospital Effluent Wastewaters. J. Chromatogr. A 2006, 1114, 224-233. [CrossRef]

5. Aitken, M.; Kleinrock, M. Global Medicines Use in 2020. Outlook and Implications. Available online: https://www.iqvia.com/-/ media/iqvia/pdfs/institute-reports/global-medicines-use-in-2020 (accessed on 18 December 2021).

6. Hughes, S.; Kay, P.; Brown, L. Global Synthesis and Critical Evaluation of Pharmaceutical Data Sets Collected from River Systems. Environ. Sci. Technol. 2012, 47, 661-677. [CrossRef]

7. Braun, P.; Lange, F.; Schrader, S.; Lorenz, W. Determination of Endocrine Disrupting Compounds and Acidic Drugs in Water by Coupling of Derivatization, Gas Chromatography and Negative-Chemical Ionization Mass Spectrometry. Clean 2007, 35, 444-451. [CrossRef]

8. Cleuvers, M. Mixture Toxicity of the Anti-Inflammatory Drugs Diclofenac, Ibuprofen, Naproxen, and Acetylsalicylic Acid. Ecotoxicol. Environ. Saf. 2004, 59, 309-315. [CrossRef]

9. RFDTV, PAP and Paracetamol Market Size In 2021: Top Countries Data with 2.0\% CAGR, Global Industry Brief Analysis by Top Key companies and Growth Insights to 2027. Latest 136 Pages Report. Available online: https://www.rfdtv.com/story/4467 0147 / pap-and-paracetamol-market-size-in-2021-top-countries-data-with-20-cagr-global-industry-brief-analysis-by-top-keycompanies-and-growth-insights-to (accessed on 19 December 2021).

10. Al-Kaf, A.G.; Naji, K.M.; Abdullah, Q.Y.M.; Edrees, W.H.A. Occurrence of Paracetamol in Aquatic Environments and Transformation by Microorganisms: A Review. Chron. Pharm. Sci. 2017, 1, 341-355.

11. Zhang, Z.; Lin, F.; Xiang, L.; Yu, H.; Wang, Z.; Yan, B.; Chen, G. Synergistic effect for simultaneously catalytic ozonation of chlorobenzene and $\mathrm{NO}$ over $\mathrm{MnCoO}$ catalysts: Byproducts formation under practical conditions. Chem. Eng. J. 2022, 427, 130929. [CrossRef]

12. Yuan, Y.; Garg, S.; Wang, Y.; Li, W.; Chen, G.; Gao, M.; Zhong, J.; Wang, J.; Waite, T.D. Influence of salinity on the heterogeneous catalytic ozonation process: Implications to treatment of high salinity wastewater. J. Hazard. Mat. 2022, 423, 127255. [CrossRef]

13. Wang, Z.; Xian, W.; Ma, Y.; Xu, T.; Jiang, R.; Zhu, H.; Mao, X. Catalytic ozonation with disilicate-modified nZVI for quinoline removal in aqueous solution: Efficiency and heterogeneous reaction mechanism. Sep. Purif. Technol. 2022, 281, 119961. [CrossRef]

14. Shao, S.; Li, Z.; Gao, K.; Zhang, J.; Liu, Y.; Jiao, W. Preparation of Cu-MnO $\mathrm{X}_{X} / \gamma-\mathrm{Al}_{2} \mathrm{O}_{3}$ by high gravity-assisted impregnation method for heterogeneous catalytic ozonation of nitrobenzene. Sep. Purif. Technol. 2022, 280, 119896. [CrossRef]

15. Kohantorabi, M.; Moussavi, G.; Oulego, P.; Giannakis, S. Heterogeneous catalytic ozonation and peroxone-mediated removal of Acetaminophen using natural and modified hematite-rich soil, as efficient and environmentally friendly catalysts. Appl. Catal. $B$ Environ. 2022, 301, 120786. [CrossRef]

16. Heidari, Z.; Pelalak, R.; Eshaghi Malekshah, R.; Pishnamazi, M.; Rezakazemi, M.; Aminabhavi, T.M.; Shirazian, S. A new insight into catalytic ozonation of sulfasalazine antibiotic by plasma-treated limonite nanostructures: Experimental, modeling and mechanism. Chem. Eng. J. 2022, 428, 131230. [CrossRef]

17. Guan, Z.; Guo, Y.; Huang, Z.; Liao, X.; Chen, S.; Ou, X.; Sun, S.; Liang, J.; Cai, Y.; Xie, W.; et al. Simultaneous and efficient removal of organic $\mathrm{Ni}$ and $\mathrm{Cu}$ complexes from electroless plating effluent using integrated catalytic ozonation and chelating precipitation process in a continuous pilot-scale system. Chem. Eng. J. 2022, 428, 131250. [CrossRef]

18. Zuo, X.; Ma, S.; Wu, Q.; Xiong, J.; He, J.; Ma, C.; Chen, Z. Nanometer $\mathrm{CeO}_{2}$ doped high silica ZSM-5 heterogeneous catalytic ozonation of sulfamethoxazole in water. J. Hazard. Mater. 2021, 411, 125072. [CrossRef] 
19. Zhang, Z.; Ai, H.; Fu, M.-L.; Hu, Y.-b.; Liu, J.; Ji, Y.; Vasanthakumar, V.; Yuan, B. A new insight into catalytic ozonation of ammonia by $\mathrm{MgO} / \mathrm{Co}_{3} \mathrm{O}_{4}$ composite: The effects, reaction kinetics and mechanism. Chem. Eng. J. 2021, 418, 129461. [CrossRef]

20. Zhang, J.; Xin, B.; Shan, C.; Zhang, W.; Dionysiou, D.D.; Pan, B. Roles of oxygen-containing functional groups of O-doped g-C ${ }_{3} N_{4}$ in catalytic ozonation: Quantitative relationship and first-principles investigation. Appl. Catal. B Environ. 2021, $292,120155$. [CrossRef]

21. Zhang, F.; Liao, J.; Lu, J.; Niu, J. Extensive incorporation of carboxyl groups into g- $\mathrm{C}_{3} \mathrm{~N}_{4}$ by integrated oxygen doping and $\mathrm{HNO}_{3}$ oxidation for enhanced catalytic ozonation of para-chlorobenzoic acid and atrazine. Sep. Purif. Technol. 2021, 256, 117806. [CrossRef]

22. Tang, X.; Zhang, Y.; Li, W.; Geng, J.; Ren, H.; Xu, K. Mechanism and toxicity evaluation of catalytic ozonation over $\mathrm{Cu} / \mathrm{Ce}-\mathrm{Al}_{2} \mathrm{O}_{3}$ system aiming at degradation of humic acid in real wastewater. Sci. Rep. 2021, 11, 8748. [CrossRef]

23. Sun, Z.; Ma, J.; Liu, Y.; Wang, H.; Cao, W.; Zhu, N.; Lou, Z. Mineralization of refractory organics in oil refinery wastewater by the catalytic ozonation with magnetic praseodymium-catalysts: Catalytic performances and mechanisms. Sep. Purif. Technol. 2021, 277, 119506. [CrossRef]

24. Suligoj, A.; Kete, M.; Cernigoj, U.; Fresno, F.; Lavrencic Stangar, U. Synergism in $\mathrm{TiO}_{2}$ photocatalytic ozonation for the removal of dichloroacetic acid and thiacloprid. Environ. Res. 2021, 197, 110982. [CrossRef]

25. Song, J.; Ma, N.; Chen, W.; Chen, J.; Dai, Q. Insights into mechanism of catalytic ozonation of cinnamyl alcohol over core-shell $\mathrm{Fe}_{3} \mathrm{O}_{4} @ \mathrm{SiO}_{2} @ \mathrm{La}_{2} \mathrm{O}_{3}$ catalyst. Sep. Purif. Technol. 2021, 282, 119969. [CrossRef]

26. Ren, H.; Wang, Z.; Chen, X.; Jing, Z.; Qu, Z.; Huang, L. Effective mineralization of p-nitrophenol by catalytic ozonation using Ce-substituted $\mathrm{La}_{1 x} \mathrm{Ce}_{x} \mathrm{FeO}_{3}$ catalyst. Chemosphere 2021, 285, 131473. [CrossRef]

27. Rashidashmagh, F.; Doekhi-Bennani, Y.; Tizghadam-Ghazani, M.; van der Hoek, J.P.; Mashayekh-Salehi, A.; Heijman, B.; Yaghmaeian, K. Synthesis and characterization of $\mathrm{SnO}_{2}$ crystalline nanoparticles: A new approach for enhancing the catalytic ozonation of acetaminophen. J. Hazard. Mater. 2021, 404, 124154. [CrossRef]

28. Psaltou, S.; Kaprara, E.; Triantafyllidis, K.; Mitrakas, M.; Zouboulis, A. Heterogeneous catalytic ozonation: The significant contribution of PZC value and wettability of the catalysts. J. Environ. Chem. Eng. 2021, 9, 106173. [CrossRef]

29. Mu, J.; Li, S.; Wang, J.; Li, X.; Chen, W.; Tong, X.; Tang, Y.; Li, L. Efficient catalytic ozonation of bisphenol A by three-dimensional mesoporous $\mathrm{CeO}_{\mathrm{x}}$-loaded SBA-16. Chemosphere 2021, 278, 130412. [CrossRef]

30. Meng, F.; Guo, L.; He, J.; Wang, Z.; Ma, Z.; Zeng, Y.; Zhang, S.; Zhong, Q. $\mathrm{V}_{2} \mathrm{O}_{5}-\left(\mathrm{NH}_{4}\right)_{2} \mathrm{~V}_{6} \mathrm{O}_{16} \cdot 1.5 \mathrm{H}_{2} \mathrm{O}$ composite catalysts as novel platforms for high-efficiency catalytic ozonation of NO under low temperature. J. Phys. Chem. Solids 2021, 155, 110112. [CrossRef]

31. Zhao, Y.; An, H.; Dong, G.; Feng, J.; Ren, Y.; Wei, T. Elevated removal of di-n-butyl phthalate by catalytic ozonation over magnetic Mn-doped ferrospinel $\mathrm{ZnFe}_{2} \mathrm{O}_{4}$ materials: Efficiency and mechanism. Appl. Surf. Sci. 2020, 505, 144476. [CrossRef]

32. Zhang, H.; He, Y.; Lai, L.; Yao, G.; Lai, B. Catalytic ozonation of Bisphenol A in aqueous solution by $\mathrm{Fe}_{3} \mathrm{O}_{4}-\mathrm{MnO}_{2} \mathrm{magnetic}$ composites: Performance, transformation pathways and mechanism. Sep. Purif. Technol. 2020, 245, 116449. [CrossRef]

33. Chávez, A.M.; Solís, R.R.; Beltrán, F.J. Magnetic graphene $\mathrm{TiO}_{2}$-based photocatalyst for the removal of pollutants of emerging concern in water by simulated sunlight aided photocatalytic ozonation. Appl. Catal. B Environ. 2020, 262, 118275. [CrossRef]

34. Chávez, A.M.; Quiñones, D.H.; Rey, A.; Beltrán, F.J.; Álvarez, P.M. Simulated solar photocatalytic ozonation of contaminants of emerging concern and effluent organic matter in secondary effluents by a reusable magnetic catalyst. Chem. Eng. J. 2020, 398, 125642. [CrossRef]

35. Asgari, E.; Farzadkia, M.; Esrafili, A.; Badi, M.Y.; Jokandan, S.F.; Sobhi, H.R. Application of a photocatalytic ozonation process using $\mathrm{TiO}_{2}$ magnetic nanoparticles for the removal of Ceftazide from aqueous solutions: Evaluation of performance, comparative study and mechanism. Optik 2020, 212, 164667. [CrossRef]

36. Orge, C.A.; Soares, O.S.G.P.; Ramalho, P.S.F.; Pereira, M.F.R.; Faria, J.L. Magnetic Nanoparticles for Photocatalytic Ozonation of Organic Pollutants. Catalysts 2019, 9, 703. [CrossRef]

37. Yusuf, M.A.; Abidin, K.; Eliyana, A.; Malago, J.D.; Noor, F.A.; Winata, T. Nickel thin film preparation and its characterization as catalyst for HWC-in plasma-PECVD-growth graphene. Mat. Today Proc. 2021, 44, 3420-3425. [CrossRef]

38. Hosseini, A.; Karimi, H.; Foroughi, J.; Sabzehmeidani, M.M.; Ghaedi, M. Heterogeneous photoelectro-Fenton using ZnO and $\mathrm{TiO}_{2}$ thin film as photocatalyst for photocatalytic degradation Malachite Green. Appl. Surf. Sci. Adv. 2021, 6, 100126. [CrossRef]

39. Zhang, X.; Ptasinska, S. Dissociative adsorption of $\mathrm{H}_{2} \mathrm{O}$ onto a Pt thin film in direct contact with GaN (0001): Effect of electronic communications between catalyst and a semiconducting support. Appl. Surf. Sci. 2020, 516, 146127. [CrossRef]

40. Mauraya, A.K.; Mahana, D.; Pal, P.; Muthiah, S.; Singh, P.; Muthusamy, S.K. Effect of bulk and surface modification of SnO 2 thin films with $\mathrm{PdO}$ catalyst on $\mathrm{CO}$ gas sensing characteristics prepared by vacuum evaporation process. J. Alloys Compd. 2020, 843, 155979. [CrossRef]

41. Sankarasubramanian, K.; Babu, K.J.; Soundarrajan, P.; Logu, T.; Gnanakumar, G.; Ramamurthi, K.; Sethuraman, K.; Senthil Kumar, S.M. A new catalyst Ti doped $\mathrm{CdO}$ thin film for non-enzymatic hydrogen peroxide sensor application. Sens. Actuators B Chem. 2019, 285, 164-172. [CrossRef]

42. Tyagi, P.; Sharma, A.; Tomar, M.; Gupta, V. $\mathrm{SnO}_{2}$ thin film sensor having $\mathrm{NiO}$ catalyst for detection of $\mathrm{SO}_{2}$ gas with improved response characteristics. Sens. Actuators B Chem. 2017, 248, 998-1005. [CrossRef]

43. Li, Y.; Song, W.; Liu, J.; Zhao, Z.; Gao, M.; Wei, Y.; Wang, Q.; Deng, J. The protection of $\mathrm{CeO}_{2}$ thin film on Cu-SAPO-18 catalyst for highly stable catalytic $\mathrm{NH}_{3}$-SCR performance. Chem. Eng. J. 2017, 330, 926-935. [CrossRef] 
44. Fatahpour, M.; Noori Sadeh, F.; Hazeri, N.; Maghsoodlou, M.T.; Hadavi, M.S.; Mahnaei, S. Ag/TiO ${ }_{2}$ nano-thin films as robust heterogeneous catalyst for one-pot, multi-component synthesis of bis (pyrazol-5-ol) and dihydropyrano[2,3-c]pyrazole analogs. J. Saudi Chem. Soc. 2017, 21, 998-1006. [CrossRef]

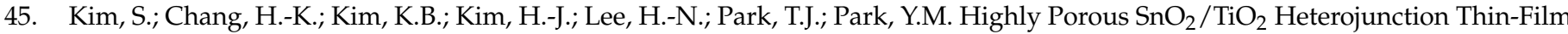
Photocatalyst Using Gas-Flow Thermal Evaporation and Atomic Layer Deposition. Catalysts 2021, 11, 1144. [CrossRef]

46. Zhao, W.; Yang, X.; Liu, C.; Qian, X.; Wen, Y.; Yang, Q.; Sun, T.; Chang, W.; Liu, X.; Chen, Z. Facile Construction of All-Solid-State Z-Scheme g- $\mathrm{C}_{3} \mathrm{~N}_{4} / \mathrm{TiO}_{2}$ Thin Film for the Efficient Visible-Light Degradation of Organic Pollutant. Nanomaterials 2020, 10, 600 [CrossRef]

47. Nicosia, A.; Vento, F.; Di Mari, G.M.; D’Urso, L.; Mineo, P.G. TiO ${ }_{2}$-Based Nanocomposites Thin Film Having Boosted Photocatalytic Activity for XenobioticsWater Pollution Remediation. Nanomaterials 2021, 11, 400. [CrossRef]

48. Stathatos, E.; Lianos, P.; Tsakiroglou, C. Highly efficient nanocrystalline titania films made from organic/inorganic nanocomposite gels. Micropor. Mesopor. Mat. 2004, 75, 255-260. [CrossRef]

49. Zheng, Z.; Ng, Y.H.; Tang, Y.; Li, Y.; Chen, W.; Wang, J.; Li, X.; Li, L. Visible-light-driven photoelectrocatalytic activation of chloride by nanoporous $\mathrm{MoS}_{2} @ \mathrm{BiVO}_{4}$ photoanode for enhanced degradation of bisphenol A. Chemosphere 2020, 263, 128279. [CrossRef]

50. Pinar Gokdemir, F.; Ece Yuzbasioglu, V.; Keskin, B.; Ozdemir, O.; Kutlu, K. Formation of TiO 2 Thin Films by a Modified Sol-gel Route and Characterization of Structural, Optical and Electrochromic Properties. Adv. Mat. Lett. 2014, 5, 367-371. [CrossRef]

51. Haider, A.J.; Thamir, A.D.; Najim, A.A.; Ali, G.A. Improving Efficiency of $\mathrm{TiO}_{2}: \mathrm{Ag} / \mathrm{Si}$ Solar Cell Prepared by Pulsed Laser Deposition. Plasmonics 2016, 12, 105-115. [CrossRef]

52. Thamaphat, K.; Limsuwan, P.; Ngotawornchai, B. Phase characterization of $\mathrm{TiO}_{2}$ powder by XRD and TEM. Kasetsart J. 2008, 42 , 357-361.

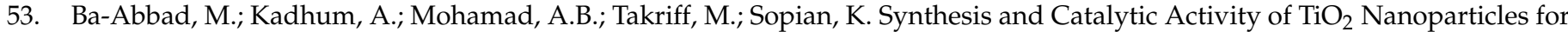
Photochemical Oxidation of Concentrated Chlorophenols under Direct Solar Radiation. Int. J. Electrochem. Sci. 2012, 7, 4871-4888

54. Avciata, O.; Benli, Y.; Gördük, S.; Gördük, Ö. Ag doped $\mathrm{TiO}_{2}$ nanoparticles prepared by hydrothermal method and coating of the nanoparticles on the ceramic pellets for photocatalytic study: Surface properties and photoactivity. J. Eng. Technol. Appl. Sci. 2016, 1, 34-50. [CrossRef]

55. Wei, C.H.; Tang, X.H.; Liang, J.R.; Tan, S.Y. Preparation, characterization and photocatalytic activities of boron- and ceriumcodoped $\mathrm{TiO}_{2}$. J. Environ. Sci. 2007, 19, 90-96. [CrossRef]

56. Hassan, M.S.; Amna, T.; Al-Deyab, S.S.; Kim, H.C.; Oh, T.H.; Khil, M.S. Toxicity of $\mathrm{Ce}_{2} \mathrm{O}_{3} / \mathrm{TiO}_{2}$ composite nanofibers against $\mathrm{S}$ aureus and S. typhimurium: A novel electrospun material for disinfection of food pathogens. Colloids Surf. A Physicochem. Eng. Asp. 2012, 415, 268-273. [CrossRef]

57. Patel, S.B.; Radevski, N.; Mondinos, N.; Zhao, X.; Jack, K.; Veder, J.P.; Zhou, Z.F.; Jiang, Z.T. A mechanical and modelling study of magnetron sputtered cerium-titanium oxide film coatings on Si (100). Ceram. Int. 2019, 45, 6875-6884. [CrossRef]

58. Duan, N.; Lin, H.; Li, L.; Hu, J.; Bi, L.; Lu, H.; Weng, X.; Xie, J.; Deng, L. $\mathrm{ZrO}_{2}-\mathrm{TiO}_{2}$ thin films: A new material system for mid-infrared integrated photonics. Opt. Mater. Express 2013, 3, 1537-1545. [CrossRef]

59. Lubas, M.; Jasinski, J.J.; Sitarz, M.; Kurpaska, L.; Podsiad, P.; Jasinski, J. Raman spectroscopy of TiO ${ }_{2}$ thin films formed by hybrid treatment for biomedical applications. Spectrochim Acta A Mol. Biomol. Spectrosc. 2014, 133, 867-871. [CrossRef]

60. Balzano, V.; Cavaliere, E.; Fanetti, M.; Gardonio, S.; Gavioli, L. The Role of Substrate on Thermal Evolution of Ag/TiO 2 Nanogranular Thin Films. Nanomaterials 2021, 11, 2253. [CrossRef]

61. Medjaldi, F.; Bouabellou, A.; Bouachiba, Y.; Taabouche, A.; Bouatia, K.; Serrar, H. Study of $\mathrm{TiO}_{2}, \mathrm{SnO}_{2}$ and nanocomposites $\mathrm{TiO}_{2}: \mathrm{SnO}_{2}$ thin films prepared by sol-gel method: Successful elaboration of variable-refractive index systems. Mat. Res. Express 2020, 7, 016439. [CrossRef]

62. Topuz, B.B.; Gündüz, G.; Mavis, B.; Çolak, Ü. The effect of tin dioxide $\left(\mathrm{SnO}_{2}\right)$ on the anatase-rutile phase transformation of titania $\left(\mathrm{TiO}_{2}\right)$ in mica-titania pigments and their use in paint. Dyes Pigm. 2011, 90, 123-128. [CrossRef]

63. Mosquera, A.A.; Albella, J.M.; Navarro, V.; Bhattacharyya, D.; Endrino, J.L. Effect of silver on the phase transition and wettability of titanium oxide films. Sci. Rep. 2016, 6, 32171. [CrossRef] [PubMed]

64. Kabir, I.; Sheppard, L.; Shhamiri, R.; Koshy, P.; Liu, R.; Joe, W.; Le, A.; Lu, X.; Chen, W.F.; Sorrell, C. Correction to: Contamination of $\mathrm{TiO}_{2}$ thin films spin coated on borosilicate and rutile substrates. J. Mat. Sci. 2021, 56, 18341-18343. [CrossRef]

65. Singhal, A.; Ebrahimi, F.; Hosseini, S. A comprehensive review on the modeling of smart piezoelectric structures. Struct. Eng. Mech. 2020, 74, 611-633.

66. Olkun, A.; Pat, S.; Akkurt Özgür, N.; Mohammadigharehbagh, R.; Demirkol, U.; Özgür, M.; Korkmaz, Ş. Detailed transmittance analysis of high-performance $\mathrm{SnO}_{2}$-doped $\mathrm{WO}_{3}$ thin films in UV-Vis region for electrochromic devices. J. Mat. Sci. Mat. Electron. 2020, 27, 19074-19084. [CrossRef]

67. Yoneyama, H.; Haga, S.; Yamanaka, S. Photocatalytic activities of microcrystalline titania incorporated in sheet silicates of clay. J. Phys. Chem. 1989, 93, 4833-4837. [CrossRef]

68. Kabir, I.I.; Sheppard, L.R.; Shahmiri, R.; Liu, R.; Le, A.; Lu, X.; Hanaor, D.; Chen, W.F.; Koshy, P.; Sorrell, C.C. Correction to: Contamination of $\mathrm{TiO}_{2}$ thin films spin coated on rutile and soda-lime-silica substrates. J. Mat. Sci. 2021, 56, 17874-17875. [CrossRef]

69. Zhao, J.; Cao, J.; Zhao, Y.; Zhang, T.; Zheng, D.; Li, C. Catalytic ozonation treatment of papermaking wastewater by Ag-doped $\mathrm{NiFe}_{2} \mathrm{O}_{4}$ : Performance and mechanism. J. Environ. Sci. 2020, 97, 75-84. [CrossRef] 
70. Xu, B.; Zhou, J.L.; Altaee, A.; Ahmed, M.B.; Johir, M.A.H.; Ren, J.; Li, X. Improved photocatalysis of perfluorooctanoic acid in water and wastewater by $\mathrm{Ga}_{2} \mathrm{O}_{3} / \mathrm{UV}$ system assisted by peroxymonosulfate. Chemosphere 2020, 239, 124722. [CrossRef]

71. Wang, L.; Zhang, Q.; Chen, B.; Bu, Y.; Chen, Y.; Ma, J.; Rosario-Ortiz, F.L. Photolysis and photocatalysis of haloacetic acids in water: A review of kinetics, influencing factors, products, pathways, and mechanisms. J. Hazard. Mater. 2020, $391,122143$. [CrossRef]

72. Tan, C.; Wu, H.; He, H.; Lu, X.; Gao, H.; Deng, J.; Chu, W. Anti-inflammatory drugs degradation during LED-UV365 photolysis of free chlorine: Roles of reactive oxidative species and formation of disinfection by-products. Water Res. 2020, 185, 116252. [CrossRef]

73. Park, K.Y.; Yu, Y.J.; Yun, S.J.; Kweon, J.H. Natural organic matter removal from algal-rich water and disinfection by-products formation potential reduction by powdered activated carbon adsorption. J. Environ. Manag. 2019, 235, 310-318. [CrossRef]

74. Majumder, A.; Gupta, B.; Gupta, A.K. Pharmaceutically active compounds in aqueous environment: A status, toxicity and insights of remediation. Environ. Res. 2019, 176, 108542. [CrossRef]

75. Sorlini, S. Natural Organic Matter: Characterization and Removal by AOPs to Assist Drinking Water Facilities. In Applications of Advanced Oxidation Processes (AOPs) in Drinking Water Treatment; Gil, A., Galeano, L.A., Vicente, M.A., Eds.; Springer: Cham, Switzerland, 2017; pp. 53-68.

76. Ghosh, D.; Mondal, S.; Ramakrishna, K. Pharmacobotanical, physicochemical and phytochemical characterisation of a rare salt-secreting mangrove Aegialitis rotundifolia Roxb., (Plumbaginaceae) leaves: A comprehensive pharmacognostical study. South Afr. J. Bot. 2017, 113, 212-229. [CrossRef]

77. Ganiyu, S.O.; Oturan, N.; Raffy, S.; Cretin, M.; Causserand, C.; Oturan, M.A. Efficiency of plasma elaborated sub-stoichiometric titanium oxide $\left(\mathrm{Ti}_{4} \mathrm{O}_{7}\right)$ ceramic electrode for advanced electrochemical degradation of paracetamol in different electrolyte media. Sep. Purif. Technol. 2019, 208, 142-152. [CrossRef]

78. Zur, J.; Pinski, A.; Marchlewicz, A.; Hupert-Kocurek, K.; Wojcieszynska, D.; Guzik, U. Organic micropollutants paracetamol and ibuprofen-toxicity, biodegradation, and genetic background of their utilization by bacteria. Environ. Sci. Pollut. Res. 2018, 25, 21498-21524. [CrossRef]

79. Lopez Zavala, M.A.; Jaber Lara, C.R. Degradation of Paracetamol and Its Oxidation Products in Surface Water by Electrochemical Oxidation. Environ. Eng. Sci. 2018, 35, 1248-1254. [CrossRef]

80. Villota, N.; Lomas, J.M.; Camarero, L.M. Study of the paracetamol degradation pathway that generates color and turbidity in oxidized wastewaters by photo-Fenton technology. J. Photochem. Photobiol. A Chem. 2016, 329, 113-119. [CrossRef]

81. Neamtu, M.; Bobu, M.; Kettrup, A.; Siminiceanu, I. Ozone photolysis of paracetamol in aqueous solution. J. Environ. Sci. Health A Tox. Hazard. Subst. Environ. Eng. 2013, 48, 1264-1271. [CrossRef]

82. Costamagna, P.; Delucchi, M.; Busca, G.; Giordano, A. System for ammonia removal from anaerobic digestion and associated ammonium sulfate production: Simulation and design considerations. Proc. Safet. Environ. Protect. 2020, 144, 133-142. [CrossRef]

83. Liu, F.; Sun, L.; Wan, J.; Tang, A.; Deng, M.; Wu, R. Organic matter and ammonia removal by a novel integrated process of constructed wetland and microbial fuel cells. RSC Adv. 2019, 9, 5384-5393. [CrossRef]

84. Kang, W.; Chen, S.; Yu, H.; Xu, T.; Wu, S.; Wang, X.; Lu, N.; Quan, X.; Liang, H. Photocatalytic ozonation of organic pollutants in wastewater using a flowing through reactor. J. Hazard. Mater. 2021, 405, 124277. [CrossRef]

85. Chen, X.; Zhan, S.; Chen, D.; He, C.; Tian, S.; Xiong, Y. Grey Fe-CeO2- $\sigma$ for boosting photocatalytic ozonation of refractory pollutants: Roles of surface and bulk oxygen vacancies. Appl. Catal. B Environ. 2021, 286, 119928. [CrossRef]

86. Asgari, E.; Sheikhmohammadi, A.; Nourmoradi, H.; Nazari, S.; Aghanaghad, M. Degradation of ciprofloxacin by photocatalytic ozonation process under irradiation with UVA: Comparative study, performance and mechanism. Process Saf. Environ. Prot. 2021, 147, 356-366. [CrossRef]

87. Zhou, Y.; Yang, D.; Lu, C.; Dai, S.; Li, J.; Guan, W.; Li, D. Enhanced photocatalytic ozonation of 2,4-dichlorophenoxyacetic acid using P25/g- $\mathrm{C}_{3} \mathrm{~N}_{4}$ composite under visible light irradiation. Desalination Water Treat. 2020, 208, 377-385. [CrossRef]

88. Orge, C.A.; Sampaio, M.J.; Faria, J.L.; Pereira, M.F.R.; Silva, C.G. Efficiency and stability of metal-free carbon nitride in the photocatalytic ozonation of oxamic acid under visible light. J. Environ. Chem. Eng. 2020, 8, 104172. [CrossRef]

89. Bahadori, E.; Conte, F.; Tripodi, A.; Ramis, G.; Rossetti, I. Photocatalytic Selective Oxidation of Ammonia in a Semi-Batch Reactor: Unravelling the Effect of Reaction Conditions and Metal Co-Catalysts. Catalysts 2021, 11, 209. [CrossRef]

90. Joudi, F.; Naceur, J.B.; Ouertani, R.; Chtourou, R. A novel strategy to produce compact and adherent thin films of $\mathrm{SnO}_{2} / \mathrm{TiO}_{2}$ composites suitable for water splitting and pollutant degradation. J. Mater. Sci. Mat. Electron. 2018, 30, 167-179. [CrossRef]

91. Jiang, D.; Otitoju, T.A.; Ouyang, Y.; Shoparwe, N.F.; Wang, S.; Zhang, A.; Li, S. A Review on Metal Ions Modified TiO 2 for Photocatalytic Degradation of Organic Pollutants. Catalysts 2021, 11, 1039. [CrossRef]

92. Li, Y.; Li, W.; Liu, F.; Li, M.; Qi, X.; Xue, M.; Wang, Y.; Han, F. Construction of $\mathrm{CeO}_{2} / \mathrm{TiO}_{2}$ heterojunctions immobilized on activated carbon fiber and its synergetic effect between adsorption and photodegradation for toluene removal. J. Nanopart. Res. 2020, 22, 122. [CrossRef] 